\title{
Incorporating grassland management in ORCHIDEE: model description and evaluation at 11 eddy-covariance sites in Europe
}

\author{
J. F. Chang ${ }^{1}$, N. Viovy ${ }^{1}$, N. Vuichard ${ }^{1}$, P. Ciais ${ }^{1}$, T. Wang $^{1}$, A. Cozic ${ }^{1}$, R. Lardy ${ }^{2}$, A.-I. Graux ${ }^{2}$, K. Klumpp ${ }^{2}$, \\ R. Martin $^{2}$, and J.-F. Soussana ${ }^{2}$ \\ ${ }^{1}$ Laboratoire des Sciences du Climat et de l'Environnement, UMR8212, CEA-CNRS-UVSQ, \\ 91191 Gif-sur-Yvette, France \\ ${ }^{2}$ Grassland Ecosystem Research Unit, French National Institute for Agricultural Research (INRA), \\ 63100 Clermont-Ferrand, France
}

Correspondence to: J. F. Chang (jinfeng.chang@1sce.ipsl.fr)

Received: 21 March 2013 - Published in Geosci. Model Dev. Discuss.: 8 May 2013

Revised: 20 November 2013 - Accepted: 26 November 2013 - Published: 20 December 2013

\begin{abstract}
This study describes how management of grasslands is included in the Organizing Carbon and Hydrology in Dynamic Ecosystems (ORCHIDEE) process-based ecosystem model designed for large-scale applications, and how management affects modeled grassland-atmosphere $\mathrm{CO}_{2}$ fluxes. The new model, ORCHIDEE-GM (grassland management) is enabled with a management module inspired from a grassland model (PaSim, version 5.0), with two grassland management practices being considered, cutting and grazing. The evaluation of the results from ORCHIDEE compared with those of ORCHIDEE-GM at 11 European sites, equipped with eddy covariance and biometric measurements, shows that ORCHIDEE-GM can realistically capture the cut-induced seasonal variation in biometric variables (LAI: leaf area index; AGB: aboveground biomass) and in $\mathrm{CO}_{2}$ fluxes (GPP: gross primary productivity; TER: total ecosystem respiration; and NEE: net ecosystem exchange). However, improvements at grazing sites are only marginal in ORCHIDEE-GM due to the difficulty in accounting for continuous grazing disturbance and its induced complex animalvegetation interactions. Both NEE and GPP on monthly to annual timescales can be better simulated in ORCHIDEEGM than in ORCHIDEE without management. For annual $\mathrm{CO}_{2}$ fluxes, the NEE bias and RMSE (root mean square error) in ORCHIDEE-GM are reduced by $53 \%$ and $20 \%$, respectively, compared to ORCHIDEE. ORCHIDEE-GM is capable of modeling the net carbon balance (NBP) of managed temperate grasslands $\left(37 \pm 30 \mathrm{gC} \mathrm{m}^{-2} \mathrm{yr}^{-1}(P<0.01)\right.$ over the 11 sites) because the management module contains
\end{abstract}

provisions to simulate the carbon fluxes of forage yield, herbage consumption, animal respiration and methane emissions.

\section{Introduction}

Grassland is a widespread vegetation type, which covers 20 to 40 percent $\left(26.8\right.$ to 56 million $\mathrm{km}^{2}$ ) of the whole land surface on the earth, depending on the grassland definition (Suttie et al., 2005), and plays a significant role in the global carbon $(\mathrm{C})$ cycle. At the global scale, grasslands were estimated to be a net $\mathrm{C}$ sink of about $0.5 \mathrm{PgC}$ per year (Scurlock and Hall, 1998), but with considerable uncertainty. Schulze et al. (2009) recently inferred a net $C$ sink in European grasslands of $57 \pm 34 \mathrm{gC} \mathrm{m}^{-2} \mathrm{yr}^{-1}$ from a small sample of flux tower net ecosystem exchange (NEE) measurements, completed by $\mathrm{C}$ imports/exports at each site to estimate net biome production (NBP). When accounting for emissions of non$\mathrm{CO}_{2}$ greenhouse gases (GHGs) such as methane $\left(\mathrm{CH}_{4}\right)$ from grazing animals and nitrous oxide from soil nitrogen $(\mathrm{N})$ nitrification/denitrification processes, the European grasslands were estimated to be nearly neutral for their radiative forcing, with a net balance of $-14 \pm 18 \mathrm{~g} \mathrm{CO}_{2}-\mathrm{C} \mathrm{eq} \mathrm{m}^{-2} \mathrm{y}^{-1}$ (Schulze et al., 2010). Grasslands sequester $C$ in soils - and sequestration is likely favored by high belowground $\mathrm{C}$ allocation and root turnover, and possibly by $\mathrm{N}$ fertilization (Schulze et al., 2010). 
Most of grasslands are cultivated to feed animals, either directly by grazing or indirectly by grass harvest (cutting). Grassland management (including cutting, grazing and fertilization) affects the ecosystem $\mathrm{C}$, water and nutrient cycles, as well as the planetary surface energy balance (Feddema et al., 2005; Foley et al., 2005). A net sequestration of $\mathrm{C}$ in grassland soils can be caused by increased litter input associated with increased forage production (Conant et al., 2001) and/or by decreased soil organic matter decomposition, for instance in response to $\mathrm{N}$ additions (Berg and Matzner, 1997). Soil $\mathrm{C}$ was observed to increase in a grazed semiarid mixedgrass rangeland (Schuman et al., 1999; Reeder and Schuman, 2002) because of an accelerated shoot turnover. However, soil $\mathrm{C}$ can also decrease in response to over grazing or poor pasture management (Fearnside and Barbosa, 1998; Abril and Bucher, 1999). Light-to-moderate stocking density was also found to increase $\mathrm{C}$ sequestration in the soil (LeCain et al., 2002; Reeder and Schuman, 2002), which was partly attributed to a more diverse plant community and a denser rooting system. Cut grasslands can also sequester C (Soussana et al., 2007), but cut European grasslands were on average found to accumulate less $C$ than grazed ones (Soussana et al., 2010). Fertilizer application also affects grassland soil C (Jones and Donnelly, 2004). In particular, a moderate N fertilization was found to increase the organic matter input to the soil more than the soil $\mathrm{C}$ mineralization, which favors $\mathrm{C}$ sequestration (Soussana et al., 2004).

A better understanding of the $\mathrm{C}$ fluxes from grassland ecosystems in response to climate and management requires not only field experiments but also the aid of simulation models. The latter aim at explicitly representing the actual systems, providing a feasible way to predict long-term (compared to experiments) response of ecosystem to external factors such as climate change and management processes. Many grassland models have been developed and applied at different scales (from the plot to the global scale). Parton et al. (1988) developed the Century model to simulate soil $\mathrm{C}, \mathrm{N}, \mathrm{P}$, and $\mathrm{S}$ dynamics. The grassland ecosystem model (GEM, Hunt et al., 1991; latest version GEM-2, Chen et al., 1996) links biochemical, biophysical and ecosystem processes in a hierarchical approach to simulate $\mathrm{C}$ and $\mathrm{N}$ cycles, but focused only on natural grasslands. A sinksource growth model for prediction of biomass productivity of Lolium perenne grasslands named Lingra (LINtul GRAss) (Schapendonk et al., 1998; Rodriguez et al., 1999) takes cut practice into account. The Simulation of Production and Utilization of Rangelands (SPUR2.4, Foy et al., 1999) model is able to track $\mathrm{C}, \mathrm{N}$, and water flows in rangeland ecosystems and predicts their response to grazing practice. The Hurley Pasture Model (HPM, Thornley, 1998) describes the C, N and water fluxes in a grazed soil-pasture-atmosphere system. The process-based model PaSim (Pasture Simulation Model; Riedo et al., 1998) was derived from the HPM to simulate $\mathrm{C}$ fluxes exchanged with vegetation, soil and animals and the atmosphere, $\mathrm{N}_{2} \mathrm{O}$ emissions from soils (Schmid et al., 2001a, b), $\mathrm{NH}_{3}$ volatilization (Riedo et al., 2002) as well as $\mathrm{CH}_{4}$ emissions from animals (Vuichard et al., 2007a), considering a range of management options ( $\mathrm{N}$ fertilization, cutting and grazing practices).

Similarly to plot-scale grassland models, dynamic global vegetation models (DGVMs) are based on equations describing biogeochemical and biophysical processes and simulate the $\mathrm{C}, \mathrm{N}$, water and energy fluxes and pools dynamics. These models are generic enough to be applied for regional budgets and long-term simulations, and some of them can be coupled with regional or global climate models. Most of them describe vegetation into few plant functional types (PFTs) (i.e., grassland, crop, forest types, etc.) that share the same set of equations and parameters. These models commonly treat grasslands as being unmanaged, thereby ignoring processes related to agriculture. Only very few DGVMs consider cultivated grasslands, and with simplifications. For example, the LPJmL model (Bondeau et al., 2007) includes an idealized "human" or "livestock" disturbance to grasslands by prescribing a removal of $50 \%$ of aboveground grass biomass (AGB) when grazing, with $5 \%$ of grazed AGB entering the litter pool and the rest (95\% of grazed AGB) returning as $\mathrm{CO}_{2}$ flux to the atmosphere.

Currently, most of the land surface models have a poor (or no) representation of the management impact on grasslands. Incorporating the grassland management into the Organizing Carbon and Hydrology in Dynamic Ecosystems (ORCHIDEE) land surface model can improve the model ability in estimating $\mathrm{C}$ balance for cultivated grasslands, which enables us to go a step further in assessing $\mathrm{C}$ dynamics attributed to climate change and human cultivation.

Here, in order to model the impacts of cultivation on European grasslands, we include parameters and functions related to management (e.g., harvested biomass, enteric $\mathrm{CH}_{4}$ emissions and animal production) in the model ORCHIDEE DGVM. The objective of this study is to improve the representation of grassland by integrating interactions between climate, grass growth and management originating from a managed grassland ecosystem model (i.e., PaSim, Vuichard et al., 2007a) (Sect. 2). Model performance of the modified model was evaluated for 11 eddy-covariance (EC) sites in Europe (Sect. 3) simulating the biometric variables and the monthly to interannual variability of $\mathrm{C}$ fluxes.

\section{Model description}

\subsection{ORCHIDEE (Organizing Carbon and Hydrology In Dynamic EcosystEms)}

ORCHIDEE is a process-driven dynamic global vegetation model (DGVM) designed to simulate $\mathrm{C}$ and water cycle from site-level to global scale (Krinner et al., 2005; Ciais et al., 2005; Piao et al., 2007). It is composed of two main modules. The SECHIBA (soil-vegetation system and the atmosphere) 
parameterization computes the energy and hydrology budget on a half-hourly basis, together with photosynthesis based on enzyme kinetics (Viovy and de Noblet, 1997). These results are fed into a module of ORCHIDEE called STOMATE, which simulates $\mathrm{C}$ dynamics on a daily basis: gross primary production (GPP) is allocated to different organs, and then respired by the plant or by soil microorganisms when parts of the plant die. These processes determine several ecosystem state variables such as leaf area index (LAI) and canopy roughness, which are fed back into SECHIBA because they control the energy and water budgets. The equations of ORCHIDEE are described in Ducoudré et al. (1993) for SECHIBA and in Krinner et al. (2005) for STOMATE, and can be found at http://orchidee.ipsl.jussieu.fr/. As in most DGVMs, the vegetation is discretized into a discrete number (13) of PFTs over the globe. For grassland, C3 and C4 grass are included and treated like unmanaged natural systems, where $\mathrm{C}$-water fluxes are only subject to atmospheric $\mathrm{CO}_{2}$ and climate changes. Here we use version 1.9.6, which can be accessed at http://forge.ipsl.jussieu.fr/orchidee/browser/tags/ ORCHIDEE_1_9_6/. The $\mathrm{N}$ cycle is not included in this version of ORCHIDEE.

\subsection{PaSim (Pasture Simulation Model)}

\subsubsection{General structure}

PaSim is a plot-scale process-based grassland model developed by Riedo et al. (1998), which simulates grassland processes at a sub-daily time step. It considers a soil-vegetationanimal-atmosphere system (with state variables expressed per $\mathrm{m}^{2}$ ) and runs over one to several years. PaSim allows simulating main grassland services such as forage and milk production, as well as the $\mathrm{C}, \mathrm{N}$, water and energy fluxes in sown and permanent grasslands. PaSim was applied on a grid to make simulations of grasslands GHG fluxes at the European scale by Vuichard et al. (2007b) and was used to run an ensemble of climate change impacts simulations on grassland services and GHG budgets at French sites (Graux et al., 2012, 2013). PaSim comprises six modules, simulating plant growth, microclimate, soil biology, soil physics, animal processes, as well as management options. The two latter modules use a daily time step, just as STOMATE does in ORCHIDEE. See Graux et al. $(2012,2013)$ for further details about the modelling of grassland processes.

\subsubsection{Management simulation}

In PaSim, management includes mineral and/or organic $\mathrm{N}$ fertilization, and cutting and grazing, which can either be set by the user or optimized by the model (Riedo et al., 2000; Vuichard et al., 2007a; Graux et al., 2011). At each cutting operation, a fraction of the shoot biomass is harvested and exported away from the grassland, and a fixed amount corresponding to the residual shoot dry matter (DM) (e.g., $\left.0.15 \mathrm{~kg} \mathrm{DM} \mathrm{m}^{-2}\right)$ is left in field. PaSim assumes that a certain amount (e.g., 5\%) of the grass harvest is lost as litter. For grazing, the version of the animal module of PaSim (version 4.5) developed by Riedo et al. (2000) was further improved by Vuichard et al. (2007a). Riedo et al. (2000) simulated animal herbage intake, milk production (MP), returns, respiration and $\mathrm{CH}_{4}$ emissions from pastures grazed by dairy cows or sheep with simplified equations. Vuichard et al. (2007a) further developed this animal module by including (i) the detrimental effect of trampling on herbage and (ii) cattle selection among shoot compartments when accounting for the grass availability and digestibility (see also Vuichard, 2005 , for detailed equations). In the version of Vuichard et al. (2007a), $\mathrm{CH}_{4}$ emissions are modeled following PinaresPatiňo et al. (2007) from an empirical-based linear regression of animal emission with digestible neutral detergent fiber intake (DNDFI) calibrated for dry and early pregnant suckler cows. Simplifications included constant animal live weight and intake capacity during simulation, a grazed only diet and a milk production calculated from the ratio of net energy requirements for lactation to the energy content of milk. In this approach, neither the type of animal production (milk, beef) nor net energy requirements for maintenance and production affected intake. In addition, animals are removed from the paddock when aboveground plant biomass (BM) is lower than a threshold set at $300 \mathrm{~kg} \mathrm{DM} \mathrm{ha}^{-1}$. Since then, the animal module of PaSim (version 5.0) has been improved to simulate mechanistically the diet intake and performances for different types of cattle (suckler cows with their calves, dairy cows and heifers) in response to elevated temperatures and management, as well as feedback to the atmosphere through enteric $\mathrm{CH}_{4}$ emissions (Graux et al., 2011).

\subsection{Coupling strategy}

To incorporate into ORCHIDEE a description of management, our approach is to take the cutting, grazing and fertilization options, and the animal module of PaSim (version 5.0, see above) and integrate them into ORCHIDEE. Each day, ORCHIDEE provides AGB to the management module to be used for cutting or grazing (Fig. 1). Taking into account the types of herbivores (different types of cattle or sheep; Sect. 2.2), the management module simulates harvested biomass, herbage intake and animal trampling during grazing, and following $\mathrm{C}$ fluxes by animal respiration, milk production, $\mathrm{CH}_{4}$ emissions, and excreta returns. Then it feeds back two variables into ORCHIDEE, the residual AGB fraction, and the newly formed litter. The litter pool of ORCHIDEE is modified from the input of harvested grass residues, manure additions, and from animal trampling effect and excreta returns. We will hereafter refer to the modified version of ORCHIDEE as ORCHIDEE-GM (grassland management). Nine parameters are required for the simulations: (i) the timing of cuts and the associated residual total shoot DM (and the residual LAI), (ii) the type of fertilizer, the 


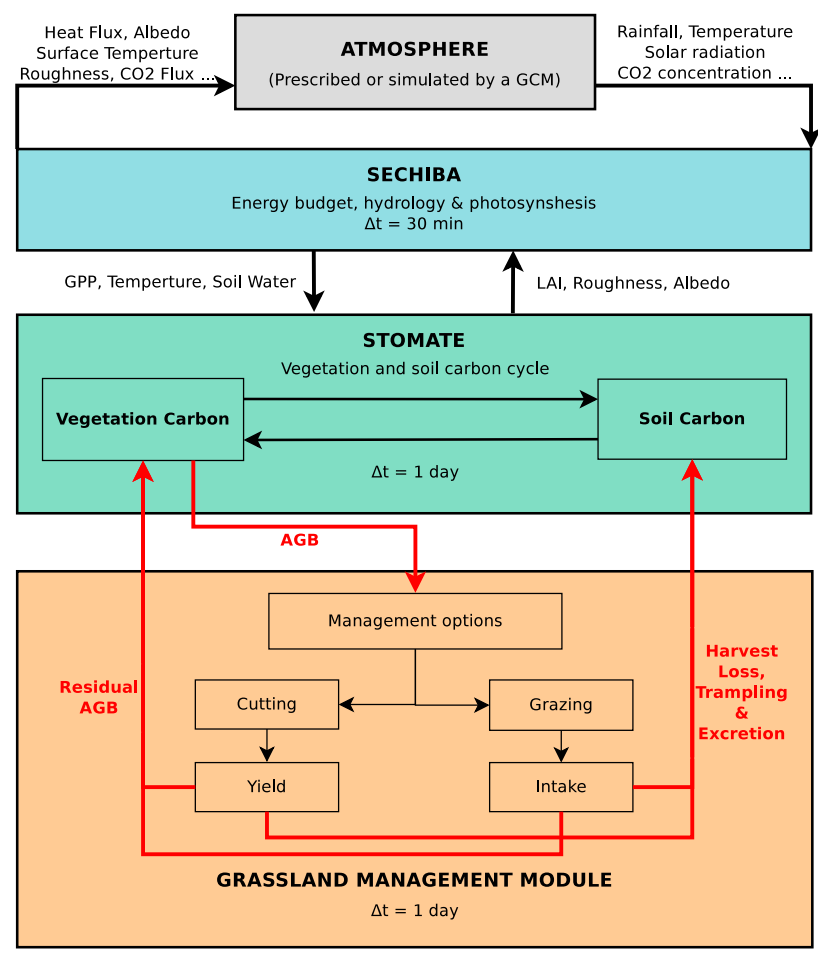

Fig. 1. Schematic of ORCHIDEE-GM.

timing of their application and the corresponding amounts, and (iii) the start and length of grazing periods and the grazing animals stocking rate $\left(n_{\text {animal }}\right)$.

\subsection{Specific modifications in the ORCHIDEE-GM}

As ORCHIDEE is designed to represent the C cycle of unmanaged grassland, we adapted the model to include (i) the possibility of reaching high LAI values such as observed in productive managed European grasslands; (ii) the leaf shed in highly dense tillers; (iii) a reduction of the leaf fraction in total AGB, and iv) a translocation of carbon from a reserve pool after cut in order to shape new leaves. In addition, we improved the representation of specific leaf area (SLA) for stimulating regrowth after cutting or grazing. These structural changes made to the ORCHIDEE-GM model code are described below.

\subsubsection{LAI limitation in managed grassland and the leaf shed in highly dense tillers}

Formerly, a limitation of LAI ( $\mathrm{LAI}_{\max }, 2.5 \mathrm{~m}^{2} \mathrm{~m}^{-2}$ for $\mathrm{C} 3$ grass) was prescribed in ORCHIDEE to avoid unrealistically high LAI of unmanaged C3 grass. However, productive grass species selected by agronomists, as well as fertilization, make higher LAI possible in grasslands. According to maximum LAI observed at 20 European grassland sites (Gilmanov et al., 2007), we alleviated the limitation of maximum seasonal LAI by increasing the $\mathrm{LAI}_{\max }$ parameter to $7 \mathrm{~m}^{2} \mathrm{~m}^{-2}$ in ORCHIDEE-GM.

Natural grasses in ORCHIDEE seldom shed new leaves during growing season unless "meteorological" leaf senescence happens (Krinner et al., 2005). However, highly dense tillers in managed grassland can induce fading of their shaded leaves at the base of the canopy. Thus we added to ORCHIDEE an AGB turnover parameter that depends on tiller density (LAI in the model). For the C pools affected by shading, the rate of loss of their biomass, $\Delta B$, is prescribed through

$\Delta B=B \frac{\Delta t}{\tau}$,

where $B$ is the biomass and $\Delta t$ is the time step of 1 day. $\tau$ (days) is assumed to be a linear function of LAI when a density of grasses $\left(2.5 \mathrm{~m}^{2} \mathrm{~m}^{-2}\right)$ is reached or surpassed:

$\tau=\max \left(\tau_{\min }, \tau_{\max }-\mathrm{LAI} \times 10\right)$ if $\mathrm{LAI}>2.5 \mathrm{~m}^{2} \mathrm{~m}^{-2}$,

with $\tau_{\min }=45$ days and $\tau_{\max }=85$ days.

\subsubsection{Reduction of leaf fraction in total AGB after harvest (cut) and following translocation from carbohydrate reserves}

During cutting operations, the upper part of AGB is removed, mainly leaves, some stems and all ears. Within the remaining part of AGB near land surface, after cutting, tissues used for sustaining and transporting (stems) become the most significant proportion of AGB. Thus in ORCHIDEE-GM, we supposed a leaf fraction of $10 \%$ and a stem fraction of $90 \%$ in the remaining AGB after a cut event.

Photosynthesis decreases dramatically just after a cut since few leaves remain. A rapid restoration of active photosynthesis is thus crucial for plant recovery after defoliation and carbohydrate reserves play a critical role in sustaining regrowth during the first days after cut (Schnyder and de Visser, 1999). To reproduce this recovery, we placed an additional translocation from the ORCHIDEE carbohydrate reserves pool toward the leaf biomass pool after each cut, just as it is the case for ORCHIDEE at the leaf onset date, in order to rapidly restore a relatively dense leaf cover (Krinner et al., 2005).

\subsubsection{Age-related SLA}

Usually, newly formed leaves have a higher specific leaf area (SLA) value, which decreases with increasing leaf age (Haase et al., 1999; Poorter et al., 2009). Age-related SLA changes were neglected in the standard version of ORCHIDEE, which has a PFT-specific, fixed SLA value. However, in managed grasslands, the age of leaves is modified by cutting/grazing, and SLA variations with leaf age become important. Newly formed leaves with higher SLA help the plant to increase rapidly its LAI with a relatively small 
amount of biomass. Therefore we let SLA depend on leaf age class and on the fraction of leaf mass in that class.

There are four leaf age classes in ORCHIDEE. At each time step, GPP allocated to leaves is incorporated into leaf biomass of age class 1 , and a fraction of the leaf biomass passes from age class $i$ to age class $i+1$. This process results in an increasing age of the canopy during the growing period. We calculated SLA as

$\mathrm{SLA}=\sum_{i=1}^{4} \operatorname{sla}_{i} \times f_{i}$

where $f_{i}$ is the fraction of leaves in age class $i$, and sla $a_{i}$ is the prescribed maximum SLA $\left(\mathrm{SLA}_{\max }\right)$ for age class $i$. The value of sla $_{1}$ equals to $\mathrm{SLA}_{\max }$, then to a fraction of $0.90,0.85$ and 0.80 of $\mathrm{SLA}_{\max }$ for leaf age class 2,3 and 4, respectively. In ORCHIDEE-GM, SLA $A_{\max }$ is set to $0.048 \mathrm{~m}^{2} \mathrm{~g}^{-1} \mathrm{C}$, a value chosen to fit the mean SLA value of $\mathrm{C} 3$ grass in the global TRY database $\left(0.0201 \mathrm{~m}^{2} \mathrm{~g}^{-1} \mathrm{DM}\right.$, equal to $0.0422 \mathrm{~m}^{2} \mathrm{~g}^{-1} \mathrm{C}$ with mean leaf carbon content per dry matter of $47.61 \%$; Kattge et al., 2011).

\section{Evaluation at European grassland sites}

\subsection{Site selection and description}

To evaluate ORCHIDEE-GM, we ran ORCHIDEE and ORCHIDEE-GM at 11 European grassland sites (Fig. 2) with contrasted management intensity, where good quality flux data (NEE, measurements by eddy-covariance (EC) technique) were collected, the data being gap-filled and partitioned to GPP and TER (total ecosystem respiration) using the CarboEurope-IP methodology (see CarboEurope-IP project, e.g., Dolman et al., 2006; Reichstein et al., 2005; Papale et al., 2006; Moffat et al., 2007; Béziat et al., 2009). The 11 sites have sufficiently detailed management records (management type, timing of cutting or grazing, and correspondingly harvest severity or stocking density). There are three cut sites, six grazed sites and two mix-managed sites. The geographic information, management type, fertilization practice, year with management or $\mathrm{C}$ fluxes records, and mean meteorological variables are listed in Table 1. It should be noted that the enhanced version of the PaSim animal module (version 5.0) was used in the simulations at FR-Lq1 and FR-Lq2, where animal type (heifers) and characteristics data were available (Graux et al., 2011). At the other grazed sites, due to the lack of such detailed input data on animals, version 4.5 animal module was used instead.

Laqueuille (FR-Lq1 and FR-Lq2) has been a 6.7 ha permanent grassland for at least $50 \mathrm{yr}$, grazed by heifers from May to October. The intensively grazed Laqueille site (FRLq1, 2.8 ha) is prescribed with a mean stocking density of $\sim 1 \mathrm{LSU} \mathrm{ha}^{-1} \mathrm{yr}^{-1}$ and is fertilized with ammonium nitrate in three splits. The extensively grazed site (FR-Lq2, 3.4 ha) is

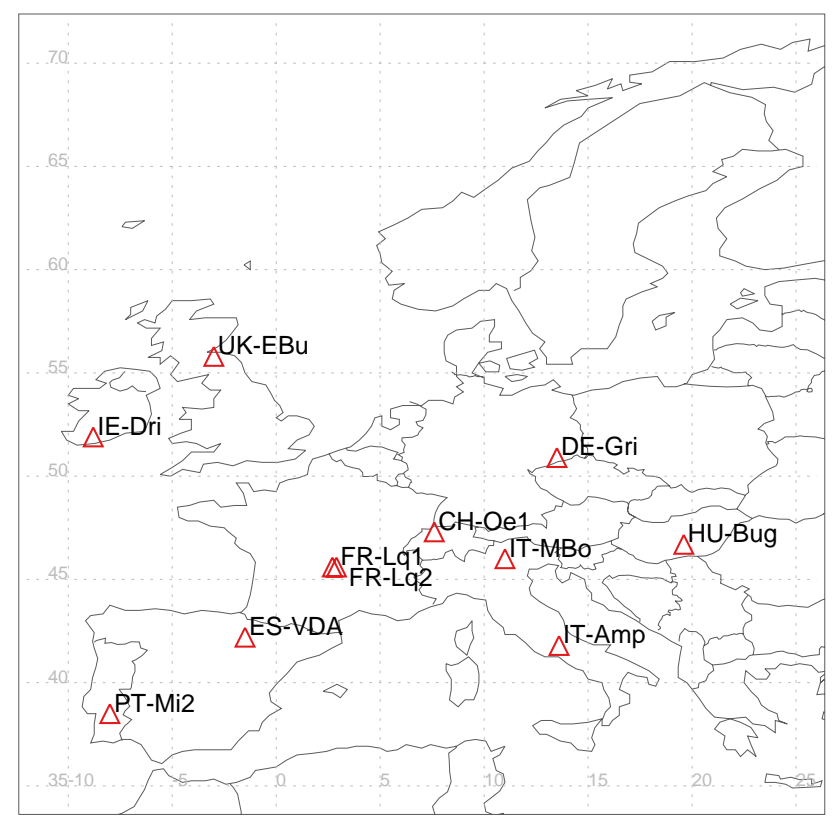

Fig. 2. Distribution of the 11 European grassland sites in this study.

maintained at half the stocking rate of the intensive paddock and is not fertilized.

Grillenburg (DE-Gri) is a permanent grass-clover mixture managed with 2-4 cuts per year and without fertilization.

Bugac (HU-Bug) is a semi-arid sandy grassland part of the Kiskunság National Park that has been under extensive management (grazing) for the last $20 \mathrm{yr}$. However, the management data are not known at this site in a protected area.

Dripsey (IE-Dri) is a perennial ryegrass pasture grazed for approximately 8 to 10 months of the year, and fertilized with $\sim 200 \mathrm{~kg} \mathrm{Nha}^{-1} \mathrm{yr}^{-1}$.

Amplero (IT-Amp) is a Mediterranean grassland site, characterized by summer drought, and is subjected to a once-ayear mowing at the peak of the growing season and some subsequent cattle grazing periods.

Monte Bondone (IT-MBo) is an alpine meadow with precipitation peaking in summer. It is managed with one cut per year in mid-July.

Mitra (PT-Mi2) is composed of C3 annuals, which dieout by the end of spring, and of one invasive $\mathrm{C} 4$ grass. The climate is Mediterranean, with a hot and dry summer, and most of the precipitation occurs between October and April. The grassland is highly seasonal. Its growth begins after the autumn rains and lasts until May-June when normally soil water content decreases strongly.

Vall d'Alinya (ES-VDA) subalpine grassland is located in the Mediterranean mountain regions of Spain, characterized by a distinct summer drought. It is moderately cattle-grazed during the summer growing season $\left(0.2-0.4 \mathrm{LSU} \mathrm{ha}^{-1}\right)$.

Oensingen (CH-Oe1) grassland has been sown with grassclover mixtures in 2001. It is cut four times a year and 
Table 1. Location, climate and management for the 11 managed grassland sites in Europe (from the FLUXNET program, http://www.fluxnet. ornl.gov; Baldocchi et al., 2001).

\begin{tabular}{|c|c|c|c|c|c|c|c|c|c|c|c|}
\hline Site & Code & Country & Latitude & Longitude & $\begin{array}{r}\text { Altitude } \\
\text { (m) }\end{array}$ & $\begin{array}{l}\text { MAT } \\
\left({ }^{\circ} \mathrm{C}\right)\end{array}$ & $\begin{array}{r}\text { MAP } \\
\left(\mathrm{mm} \mathrm{yr}^{-1}\right)\end{array}$ & Management & $\begin{array}{c}\text { Fertilization } \\
\left(\mathrm{kgN} \mathrm{yr}^{-1}\right)\end{array}$ & $\begin{array}{l}\text { Year of } \\
\text { simulation }\end{array}$ & $\begin{array}{l}\text { Year of } \\
\text { fluxes }\end{array}$ \\
\hline Laqueuille 1 & FR-Lq1 & France & $45^{\circ} 38^{\prime} \mathrm{N}$ & $02^{\circ} 44^{\prime} \mathrm{E}$ & 1040 & 7.9 & 897 & Grazing & $172-213$ & $2002-2009$ & 2004-2009 \\
\hline Laqueuille 2 & FR-Lq2 & France & $45^{\circ} 38^{\prime} \mathrm{N}$ & $02^{\circ} 44^{\prime} \mathrm{E}$ & 1040 & & & Grazing & - & 2002-2009 & 2004-2008 \\
\hline Grillenburg & DE-Gri & Germany & $50^{\circ} 57^{\prime} \mathrm{N}$ & $13^{\circ} 30^{\prime} \mathrm{E}$ & 385 & 8 & 439 & Cutting & - & 2004-2008 & 2004-2008 \\
\hline Bugac & HU-Bug & Hungary & $46^{\circ} 41^{\prime} \mathrm{N}$ & $19^{\circ} 36^{\prime} \mathrm{E}$ & 111 & 10.6 & 477 & Grazing & - & $2003-2008$ & 2003-2008 \\
\hline Dripsey & IE-Dri & Ireland & $51^{\circ} 55^{\prime} \mathrm{N}$ & $08^{\circ} 45^{\prime} \mathrm{W}$ & 186 & 9.6 & 1271 & Grazing & $\sim 200$ & $2003-2005$ & 2004-2005 \\
\hline Amplero & IT-Amp & Italy & $41^{\circ} 52^{\prime} \mathrm{N}$ & $13^{\circ} 38^{\prime} \mathrm{E}$ & 900 & 10.2 & 755 & Cutting/Grazing & - & 2003-2007 & 2003-2006 \\
\hline Monte Bondone & IT-MBo & Italy & $46^{\circ} 00^{\prime} \mathrm{N}$ & $11^{\circ} 02^{\prime} \mathrm{E}$ & 1550 & 5,1 & 999 & Cutting & - & $2003-2007$ & 2003-2007 \\
\hline Mitra & PT-Mi2 & Portugal & $38^{\circ} 32^{\prime} \mathrm{N}$ & $08^{\circ} 00^{\prime} \mathrm{W}$ & 190 & 15,6 & 550 & Cutting/Grazing & - & $2005-2007$ & 2005-2007 \\
\hline Vall d'Alinya & ES-VDA & Spain & $42^{\circ} 12^{\prime} \mathrm{N}$ & $01^{\circ} 26^{\prime} \mathrm{W}$ & 1770 & 6.5 & 891 & Grazing & - & 2004-2008 & 2004-2008 \\
\hline Oensingen & $\mathrm{CH}-\mathrm{Oe} 1$ & Switzerland & $47^{\circ} 17^{\prime} \mathrm{N}$ & $07^{\circ} 44^{\prime} \mathrm{E}$ & 450 & 9.5 & 1206 & Cutting & $\sim 200$ & 2002-2009 & 2002-2008 \\
\hline Easter Bush & $\mathrm{UK}-\mathrm{EBu}$ & United Kingdom & $55^{\circ} 52^{\prime} \mathrm{N}$ & $03^{\circ} 02^{\prime} \mathrm{W}$ & 190 & 9 & 965 & Grazing & $\sim 265$ & 2004-2008 & 2004-2008 \\
\hline
\end{tabular}

fertilizers are applied as solid ammonium nitrate or liquid cattle manure $\left(\sim 200 \mathrm{~kg} \mathrm{Nha}^{-1} \mathrm{yr}^{-1}\right)$.

Easter Bush (UK-EBu) grassland is intensively managed with cutting for silage (2002-2003) and grazing by dairy cattle and sheep (2004-2008). It receives on average $265 \mathrm{~kg} \mathrm{Nha}^{-1} \mathrm{yr}^{-1}$ as N-P-K fertilizer. The climate at this site is oceanic with mild winters and cool and moist summers.

\subsection{Meteorological data}

Meteorological data required as input by ORCHIDEE and ORCHIDEE-GM are half-hourly air temperature, precipitation (each event), wind speed, atmospheric water vapor pressure, net radiation, long-wave incoming radiation, mean near-surface atmospheric pressure and annual $\mathrm{CO}_{2}$ atmospheric concentration. All the meteorological variables were measured on top of each flux tower on a half-hour time step, meeting the requirement of the models, except for $\mathrm{CO}_{2}$, which is taken from atmospheric background measurements. The forcing data were firstly cleaned and then gap-filled according to the methods as follows (see Falge et al., 2001). For small gaps (e.g., one or two hours), linear interpolation was used; for bigger gaps (e.g., one or two days), data from days with similar pattern were adopted; for gaps longer than 10 days (e.g., in winter at cold sites, the data were gap-filled with data from similar previous year; if necessary, precipitations have been corrected in order to get the correct total annual sum. The long-wave incoming radiation (few measurements are available at the sites) and mean near surface atmospheric pressure (not measured at the sites) were extracted from the 6-hourly CRU-NCEP $0.5^{\circ} \times 0.5^{\circ}$ global database (http://www.cru.uea.ac.uk/cru/data/ncep/), which are linear interpolated to half-hourly.

\subsection{Models setup}

Site-level simulations were conducted with ORCHIDEE and with ORCHIDEE-GM separately. All simulations started from an equilibrium state of $\mathrm{C}$ pools with climate and management obtained with a model spin-up. To initialize ORCHIDEE and ORCHIDEE-GM, we first ran each model without management until all ecosystem $\mathrm{C}$ pools reached steady state ( spin-up 1); site-specific meteorological data is repeatedly cycled to force each model (Table 1 ). In reality, the equilibrium state of natural ecosystem $\mathrm{C}$ pools (after spin-up 1) can be changed by management practices. However, the management history is not clear at the site level. Thus, we assume a general (idealized) management history for each site, i.e., the same management practices as used nowadays have been applied to the additional $40 \mathrm{yr}$ after spin-up 1 to obtain the ecosystem C pools under the grassland management. Thus, starting from the end of spin-up 1 , ORCHIDEE-GM was run for another $40 \mathrm{yr}$ with the same meteorological data and management practices corresponding to the (idealized) management history of each site (spinup 2). Finally, starting from the end of spin-up 2, simulations were conducted for the target period of evaluation (Table 1).

\subsection{Methods for evaluating model performance}

To assess model-data agreement for biometric variables such as LAI and AGB, we use the index of agreement (IOA, Willmott et al., 1985; Legates and McCabe, 1999), given by

$$
\mathrm{IOA}=1.0-\sum_{i=1}^{n}\left(O_{i}-P_{i}\right)^{2} / \sum_{i=1}^{n}\left(\left|P_{i}-\bar{O}\right|+\left|O_{i}-\bar{O}\right|\right)^{2},
$$

where $P_{i}$ is modeled data, $O_{i}$ is observed data, $\bar{O}$ is observed mean, and $n$ is number of data. The index of agreement can overcome the insensitivity of correlation-based measures to differences in the observed and modeled means and variances (Willmott et al., 1985). It varies from 0.0 to 1.0, with higher values indicating better model-data agreement.

Ecosystem-atmosphere fluxes are shaped by a variety of fluctuations on different scales of characteristic variability. Scalar error estimates and residual analysis used to summarizing model-data disagreement provide only limited insight into the quality of a model (Mahecha et al., 2010). A more sophisticated way could be localizing model-data 
Table 2. Limits of the two frequency binning schemes.

\begin{tabular}{llll}
\hline Bins & Upper Limit $\mathrm{p}[\mathrm{d}] \leq \ldots$ & Lower Limit $\mathrm{p}[\mathrm{d}]>\ldots$ & Denotation \\
\hline A & maximum & 582.9 & low-frequency variability \\
B & 582.9 & 132.2 & seasonal-to-annual variability \\
C & 132.2 & 33.1 & intermonthly variability \\
D & 33.1 & minimum & daily-to-weekly variability \\
\hline
\end{tabular}

Notes: The discretization is approximately log-equidistant and provides the basis for all multiple timescales $\mathrm{CO}_{2}$ fluxes analysis. The choice of the binning is a trade-off, taking into account the requirements for an ecological interpretation and the limitations in the frequency definition of the reconstructed components (in the SSA framework).

mismatches in time (Gulden et al., 2008). Thus, to evaluate time-frequency localized model performance on $\mathrm{CO}_{2}$ fluxes (GPP, TER and NEE), we used a time domain decomposition method called SSA (singular-spectrum analysis; Broomhead and King, 1986; Elsner and Tsonis, 1996; Golyandina et al., 2001; Ghil et al., 2002). Observed and modeled time series can be described as sets of additively superimposed subsignals, which can be expressed as

$Y=\sum X_{i}, \quad i=1 \ldots N$

where $X_{i}$ is the subsignal of corresponding temporal scales. SSA is used to extract subsignals $X_{i}$ of a given time series. The SSA method was shown to be suitable for exploring the time variability of eddy-covariance ecosystematmosphere fluxes (Mahecha et al., 2007), and was used to explore model-data misfit on multiple timescales (Mahecha et al., 2010). In this study, based on the signal decomposition and reconstruction from SSA technique (Golyandina et al., 2001; for technical details see Mahecha et al., 2010, Appendix B), the original time series can be separated into four timescale variabilities: daily-to-weekly, intermonthly, seasonal-to-annual, and low-frequency (Table 2). EC observations were not fully available for all the years we simulated (Table 1). Thus, time series with continual full year gap-filled EC observations are used to derive the subsignals (time span for each site are listed in Table 1). The subsignals extracted by the SSA method provide information for a qualitative and quantitative model-data comparison on different timescales (Mahecha et al., 2010).

Model-data agreement of $\mathrm{CO}_{2}$ fluxes for each SSAextracted or combined subsignal is assessed with a Pearson's product-moment correlation coefficient $(r)$ and root mean squared error (RMSE). The Pearson's product-moment correlation coefficient $(r)$ describes the proportion of the total variance in the observed data that can be explained by the model, given by

$$
r=\frac{\sum_{i=1}^{n}\left(P_{i}-\bar{P}\right)\left(O_{i}-\bar{O}\right)}{\sqrt{\sum_{i=1}^{n}\left(P_{i}-\bar{P}\right)^{2}} \sqrt{\sum_{i=1}^{n}\left(O_{i}-\bar{O}\right)^{2}}}
$$

where $P_{i}$ is modeled data, $O_{i}$ is observed data, $\bar{P}$ is modeled mean, $\bar{O}$ is observed mean, and $n$ is the number of data. The root mean squared error (RMSE) is a measure of model accuracy reporting the mean difference between the modeled and observed fluxes, expressed as

$\mathrm{RMSE}=\sqrt{\sum_{i=1}^{n}\left(P_{i}-O_{i}\right)^{2} / n}$,

where $P_{i}$ is modeled data, $O_{i}$ is observed data, and $n$ is the number of data.

Short time span of observed $\mathrm{CO}_{2}$ fluxes reduced reliability of interannual variability extracted by SSA. Thus, we consider an ensemble approach to assess model performance for interannual variability of $\mathrm{CO}_{2}$ fluxes, which combines data of all years at all sites and gives a total of 53 site-years for the analysis. In order to quantify the interannual variability, we normalized observed-modeled $\mathrm{CO}_{2}$ fluxes by subtracting the long-term calendar year observed-modeled mean annual flux for each site-year fluxes. First, biases in model estimates of each $\mathrm{CO}_{2}$ flux are identified (observed-modeled) for calendar year average observed-modeled fluxes. Then, $r$ between observed and modeled interannual variability indicates the correlation, and RMSE is used to assess model-data agreement on long-term timescale.

\subsection{Carbon input/export and NBP calculation}

When simulating $\mathrm{CO}_{2}$ exchanges in managed grasslands, one has to take into account animal respiration in the calculation of TER at grazed sites. NEE in ORCHIDEE-GM at grazed sites is calculated as:

$\mathrm{NEE}=R_{\text {het }}+R_{\text {auto }}+R_{\text {animal }}-\mathrm{GPP}$,

where $R_{\text {het }}, R_{\text {auto }}$ and $R_{\text {animal }}$ are heterotrophic, autotrophic and animal respiration, respectively. Negative value of NEE indicates a net $\mathrm{CO}_{2}$ sink.

Besides flowing between plant, soil and atmosphere, $\mathrm{C}$ is exported by grass harvest ( $\left.C_{\text {harvest }}\right)$ and through animal products formed from grazing $\left(C_{\mathrm{CH}_{4}}, C_{\text {liveweight }}\right.$ and $\left.C_{\text {milk }}\right) ; \mathrm{C}$ is also added to the ecosystem by organic fertilizer application $\left(\mathrm{C}_{\text {fert }}\right)$. For example, slurry or manure is applied at $\mathrm{CH}-\mathrm{Oe} 1$, IE-Dri and UK-EBu (at rates of 92, 204 and $79 \mathrm{gC} \mathrm{m}^{-2} \mathrm{yr}^{-1}$, 


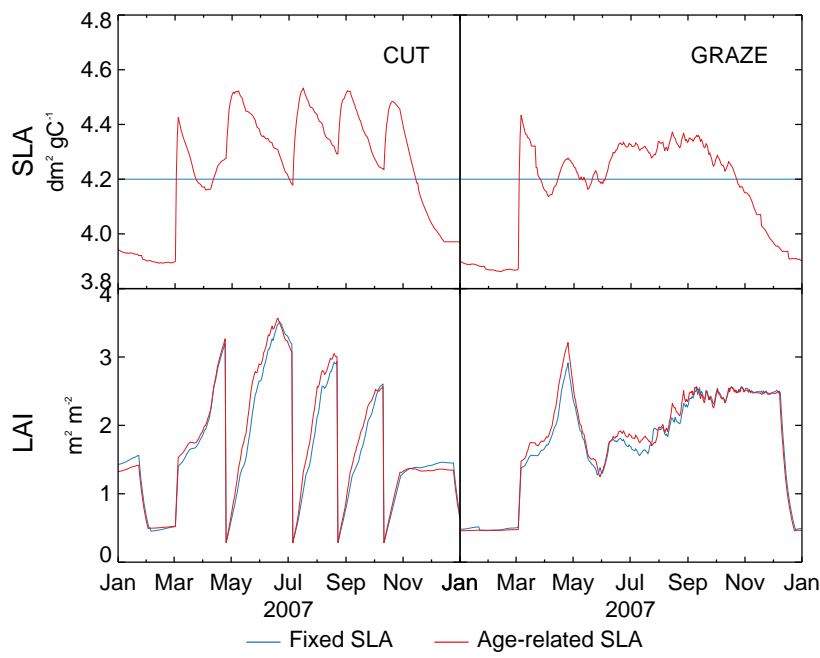

Fig. 3. Age-related SLA and its impact on LAI. Results are simulated by ORCHIDEE-GM with fixed SLA and age-related SLA respectively on a mowed grassland $(\mathrm{CH}-\mathrm{Oe} 1)$ and a grazed grassland (FR-Lq1) for the year 2007.

respectively). When $\mathrm{C}$ input/export is taken into account, the net carbon balance (NBP) of a site can be estimated as

$\mathrm{NBP}=C_{\text {fert }}-C_{\text {harvest }}-C_{\text {liveweight }}-C_{\text {milk }}-C_{\mathrm{CH}_{4}}-\mathrm{NEE}$.

Positive value of NBP indicates a net $\mathrm{C}$ sink of the ecosystem. Animal liveweight gain $\left(C_{\text {liveweight }}\right)$ during grazing comprises only little part of C export (less than $10 \%$ of $C_{\text {milk }}$; see Byrne et al., 2007). In this study, $C_{\text {liveweight was not de- }}$ termined and will be neglected for the calculation of NBP.

\section{Results}

\subsection{Age-related SLA variation and its effect on LAI}

With age-related SLA incorporated in ORCHIDEE-GM, an abrupt rise of SLA at the leaf onset and its subsequent decrease as canopy ages before the next cutting or grazing event (Fig. 3). After a cutting event, $\mathrm{C}$ translocation from carbohydrate reserves stimulates the formation of new leaves, and then the SLA begins to sharply rise again. For grazing, the SLA does not fluctuate as much as for cutting (Fig. 3), which reflects continuous biomass consumption and leaf regeneration. Finally, at the end of the growing season, SLA decreases because of leaf senescence, and a low value is maintained until the next leaf onset in spring. The average growing season SLA across the 11 sites in ORCHIDEE-GM is of $0.0424 \pm 0.0010 \mathrm{~m}^{2} \mathrm{~g}^{-1} \mathrm{C}$, which is close to the observed value of $0.0201 \mathrm{~m}^{2} \mathrm{~g}^{-1} \mathrm{DM}$ (equal to $0.0422 \mathrm{~m}^{2} \mathrm{~g}^{-1} \mathrm{C}$, with mean leaf carbon content per dry matter of $47.61 \%$ ) reported by Kattge et al. (2011) in the TRY database for 594 species (5033 observations) around the world. The dynamic SLA modeling accelerates grasses regrowth (higher LAI during
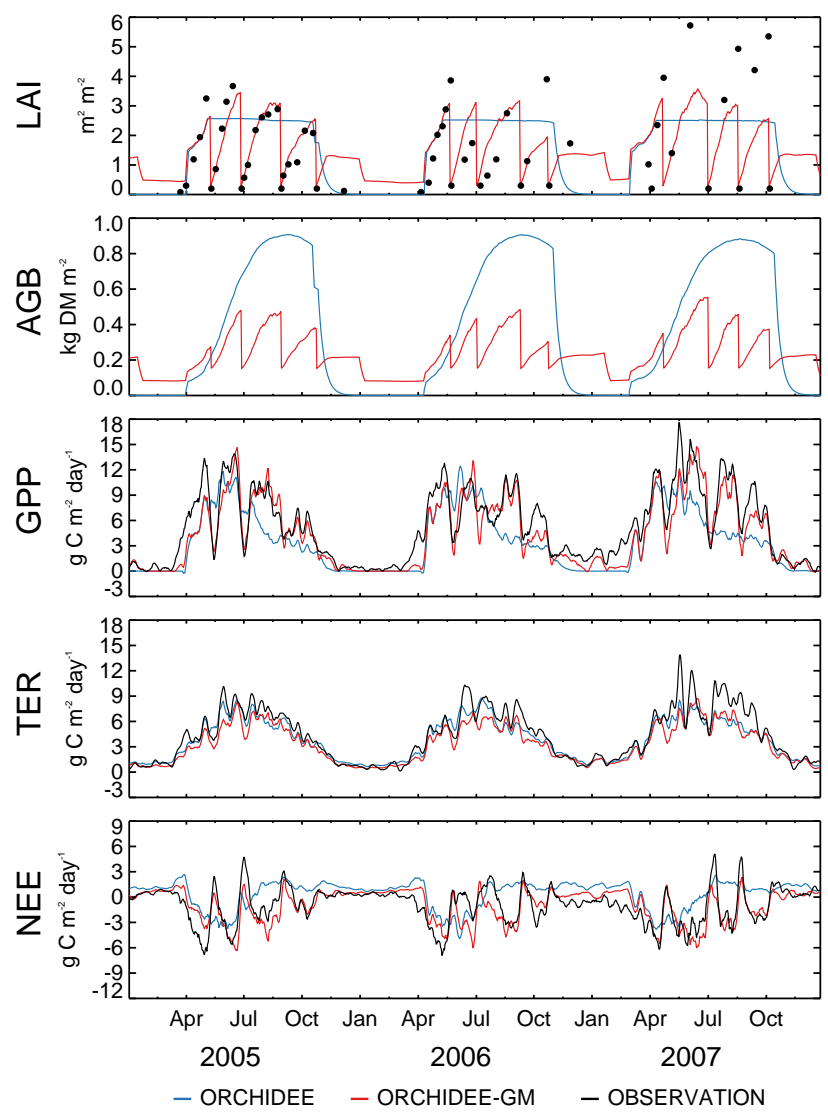

Fig. 4. Comparison of simulated/observed biometric variables and carbon fluxes for the cut grassland of Oensingen, $\mathrm{CH}-\mathrm{Oe} 1$. LAI, leaf area index; AGB, aboveground biomass (dry matter); GPP, gross primary production; TER, terrestrial ecosystem respiration; NEE, net ecosystem exchange. GPP, TER and NEE are presented as 15 day running means to smooth out very high frequencies.

growing season in Fig. 3), but the effect on LAI remains small (difference of $2.35 \%$ for annual mean LAI).

\subsection{Comparison between simulated and observed LAI, AGB and $\mathrm{CO}_{2}$ fluxes}

At the intensively managed sites (cut: $\mathrm{CH}-\mathrm{Oe} 1$ and grazed: FR-Lq1), LAI, AGB, and $\mathrm{CO}_{2}$ fluxes (GPP, TER and NEE) are compared between the two models, ORCHIDEE and ORCHIDEE-GM, and the observations (Figs. 4 and 5). In ORCHIDEE, as leaf onset is initialized, LAI steadily increases to reach its predefined maximum value $\left(2.5 \mathrm{~m}^{2} \mathrm{~m}^{-2}\right)$, which is maintained until the senescence occurs. Compared to ORCHIDEE-GM, the seasonal covariance between LAI and AGB could only be found during the periods of plant growth and senescence in ORCHIDEE (Figs. 4 and 5).

At cut site CH-Oe1, the observed LAI, AGB and GPP have dropped abruptly immediately after cutting and restore to a high values within a short time period (e.g., half-month) after cutting (Fig. 4). The same effect is also present in NEE. 

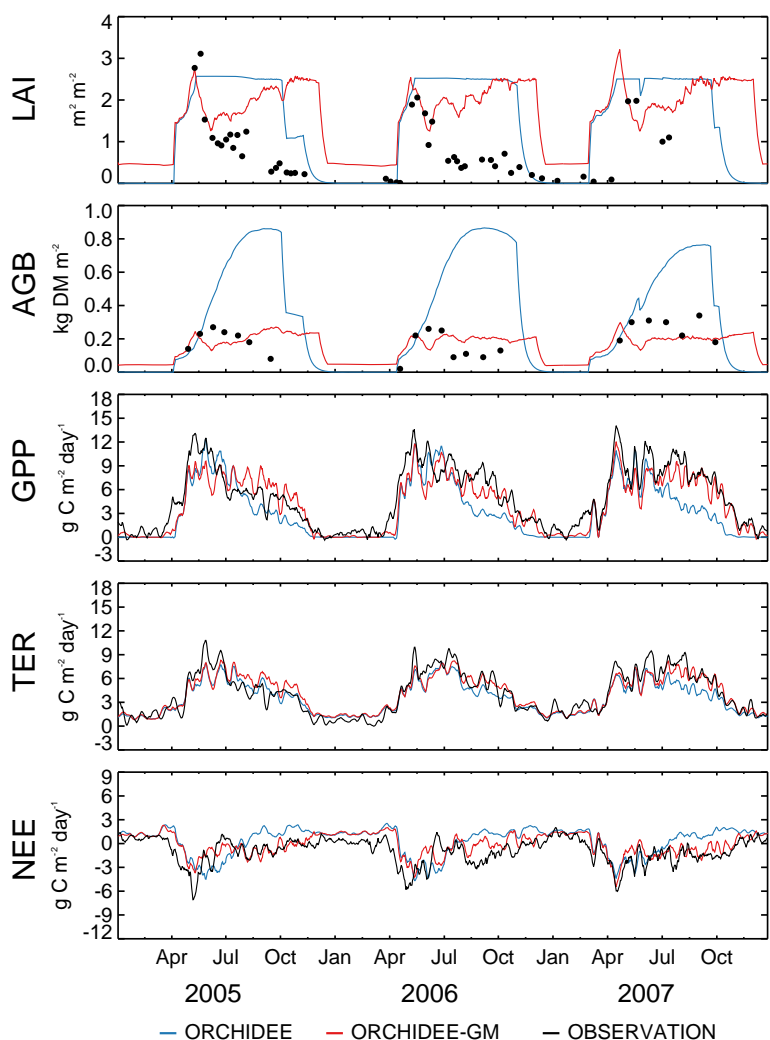

Fig. 5. Comparison of simulated/observed biometric variables and carbon fluxes for the grazed grassland of Laqueuille, FR-Lq1.

These large saw-teeth like fluctuations between two cuts are better reproduced by ORCHIDEE-GM than ORCHIDEE. However, ORCHIDEE-GM simulates lower TER than the observations (Fig. 4).

For the intensively grazed site FR-Lq1, ORCHIDEE-GM shows a moderate ability to simulate the grazing-induced AGB and LAI limitation (Fig. 5). For example, during the grazing season (May-October) the low and variable AGB and LAI values are partly captured. By contrast, ORCHIDEE without management is unable to reproduce AGB and LAI because it lacks permanent grass consumption and regrowth. ORCHIDEE-GM can simulate the seasonal cycle of NEE better than ORCHIDEE at the FR-Lq1 grazed site. As shown in Fig. 5, both observed and ORCHIDEE-GM modeled NEE switches from a strong sink of atmospheric $\mathrm{CO}_{2}$ (largest negative NEE) in early growing season (e.g., May-June in 2007) to near zero values during the peak growing - grazing season (e.g., June-July in 2007), followed by the resumption of a small $\mathrm{CO}_{2}$ sink at the end of the growing season (e.g., JulyAugust in 2007) because of grazing-stimulated grass uptake of $\mathrm{CO}_{2}$.
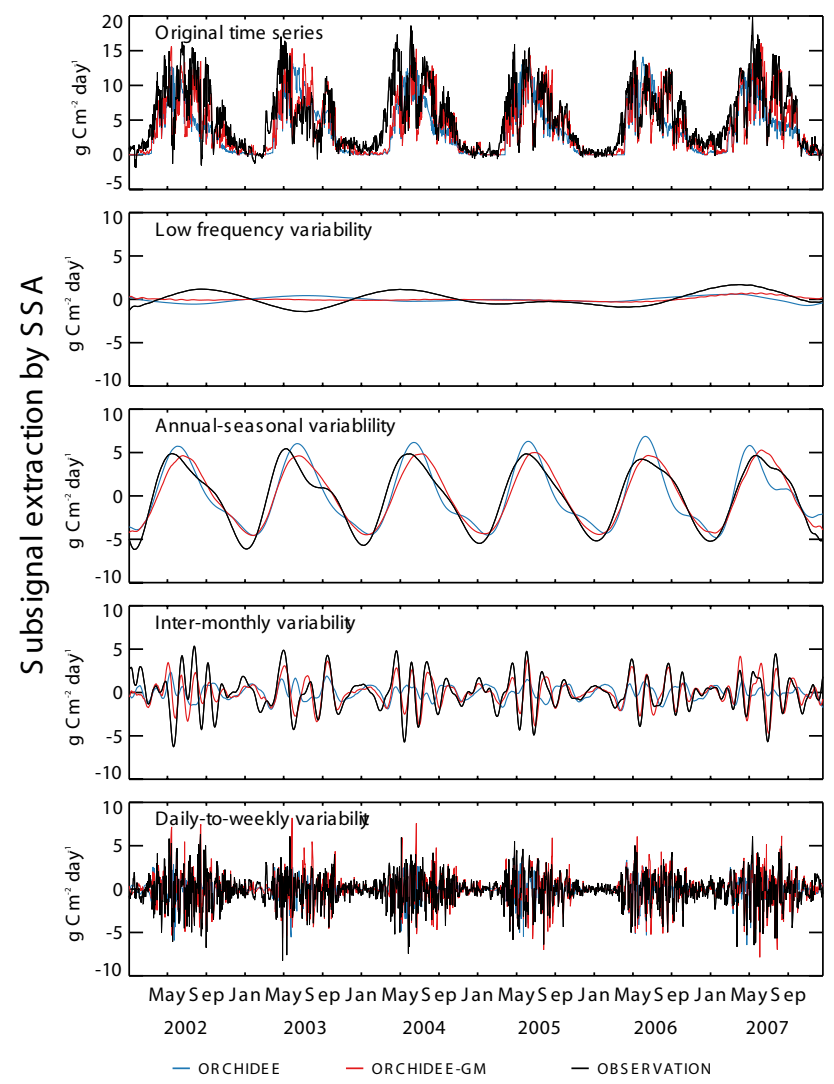

Fig. 6. Model-data comparison on multiple timescales. Observed and modeled time series are decomposed into subsignals corresponding to characteristic frequency bins. Qualitative or quantitative model-data comparisons can be carried out on the corresponding pairs of subsignals. Figure 6 exemplifies the model-data comparison with two models simulations of GPP and corresponding observations at the $\mathrm{CH}-\mathrm{Oe} 1$.

\subsection{General performance of ORCHIDEE-GM}

\subsubsection{Biometric variables}

As shown in Table 3, ORCHIDEE-GM has a greater IOA (index of agreement) (AGB: $0.80 \pm 0.22$ and LAI: $0.86 \pm 0.11$ ) than the original ORCHIDEE version (AGB: $0.33 \pm 0.21$ and LAI: $0.52 \pm 0.13)$ at the 3 cut sites $(\mathrm{CH}-\mathrm{Oe} 1, \mathrm{DE}-\mathrm{Gri}$ and IT-MBo). At the 3 grazed sites (FR-Lq1, FR-Lq2 and HUBug), ORCHIDEE-GM has comparable IOAs for LAI and relatively higher IOAs for AGB (Table 3) than ORCHIDEE. The higher IOAs in both variables are also obtained at two mixed sites (IT-Amp and PT-Mi2) for ORCHIDEE-GM. In addition, ORCHIDEE-GM has always much larger IOA values at cut sites than at grazing and mixed sites.

\subsection{2 $\mathrm{CO}_{2}$ fluxes on multiple timescales}

Figure 6 shows an example (CH-Oe1) of model-data GPP comparison on daily-to-weekly, intermonthly, 
Table 3. Index of agreement (IOA) for AGB and LAI between observation and simulation by ORCHIDEE, ORCHIDEE-GM at managed grassland sites in Europe. $N$ : number of observations.

\begin{tabular}{|c|c|c|c|c|c|c|c|}
\hline \multirow[b]{2}{*}{ Management } & \multirow[b]{2}{*}{ Site } & \multicolumn{3}{|c|}{ AGB } & \multicolumn{3}{|c|}{ LAI } \\
\hline & & ORCHIDEE & ORCHIDEE-GM & $N$ & ORCHIDEE & ORCHIDEE-GM & $N$ \\
\hline \multirow[t]{3}{*}{ Cutting } & $\mathrm{CH}-\mathrm{Oe} 1$ & 0.09 & 0.55 & 4 & 0.40 & 0.81 & 113 \\
\hline & DE-Gri & 0.45 & 0.89 & 21 & 0.66 & 0.79 & 23 \\
\hline & IT-MBo & 0.45 & 0.96 & 4 & 0.49 & 0.99 & 6 \\
\hline \multirow{3}{*}{ Grazing } & FR-Lq1 & 0.20 & 0.26 & 57 & 0.55 & 0.51 & 63 \\
\hline & FR-Lq2 & 0.35 & 0.43 & 57 & 0.56 & 0.50 & 62 \\
\hline & HU-Bug & 0.37 & 0.45 & 25 & 0.10 & 0.10 & 3 \\
\hline \multirow[t]{2}{*}{ Cutting/grazing } & IT-Amp & 0.35 & 0.68 & 40 & 0.59 & 0.66 & 36 \\
\hline & PT-Mi2 & 0.69 & 0.78 & 17 & 0.66 & 0.71 & 23 \\
\hline
\end{tabular}

seasonal-to-annual and interannual timescales. Here, only intermonthly and seasonal-to-annual time scales are discussed given the fact that grassland management processes in ORCHIDEE-GM act on GPP on these timescales. We do not conduct the model evaluation on interannual timescales because interannual variability could not be robustly extracted by SSA from the short time series. Figure 7 shows the model-data misfit (RMSE) of $\mathrm{CO}_{2}$ fluxes on seasonal-annual scales (bin B) and intermonthly scales (bin C) for all sites. The same pattern is found if $r$ is used instead of RMSE (data not shown). In general, the data shown in Fig. 7 indicate that ORCHIDEE-GM has a lower RMSE and a higher $r$ (not shown) than ORCHIDEE on both timescales.

For seasonal-annual GPP variability, ORCHIDEE-GM performs better than ORCHIDEE at all sites, excepted FRLq2 and HU-Bug. Improvement is also found at all sites for NEE. However, in contrary to GPP and NEE, improvement brought by including management is not obvious for TER. For example, most of the sites have similar RMSE values in both ORCHIDEE and ORCHIDEE-GM, a higher RMSE at HU-Bug, and a lower RMSE at IE-Dri and UKEBu found in ORCHIDEE-GM. On intermonthly scales, the behavior of ORCHIDEE-GM in TER is not significantly different from ORCHIDEE. At cut sites, ORCHIDEE-GM has a much lower RMSE than ORCHIDEE on intermonthly variability for GPP and NEE. However, this is not always found at grazed and mix-managed sites (Fig. 7).

For annual $\mathrm{CO}_{2}$ fluxes, when pooling all the site-years, ORCHIDEE-GM performs better (lower bias, higher $r$ and lower RMSE) than ORCHIDEE for GPP and NEE (Fig. 8). For example, the NEE bias and RMSE in ORCHIDEEGM is reduced by $53 \%$ and $20 \%$ respectively, compared to ORCHIDEE. Yet, the simulation of TER is not improved in ORCHIDEE-GM and its bias is even larger than ORCHIDEE, which could be attributable to two "anomalous" sites (ES-VDA and HU-Bug).

\subsubsection{Estimation of C export and NBP}

ORCHIDEE-GM has the ability to simulate $\mathrm{C}$ exports (Table 4), e.g., forage production (yield), $\mathrm{CH}_{4}$ emissions and animal products (i.e., milk) that can be evaluated against independent data. At cut sites, ORCHIDEE-GM generates 718,336 and $330 \mathrm{~g} \mathrm{DM} \mathrm{m}^{-2} \mathrm{yr}^{-1}$ for DE-Gri, IT-MBo and PT-Mi2, respectively, which is within a range of 0.88 and 2.26 factor of the observed values $(317,265$ and $374 \mathrm{~g} \mathrm{DM} \mathrm{m}^{-2} \mathrm{yr}^{-1}$ ). For annual animal intake, inter-site differences are large because of site-dependent grazing intensity. For example, the low intake values at both IT-Amp and PT-Mi2 sites are mainly attributable to extensive grazing during the winter. In addition, both animal respiration and enteric $\mathrm{CH}_{4}$ emissions produced by ORCHIDEE-GM generally show the same pattern as animal intake (Table 4), which are as a function of animal intake and the time period the animals stay in the field.

After accounting for $\mathrm{C}$ export (input) from (to) the site, ORCHIDEE-GM estimates a positive NBP of $37 \pm$ $30 \mathrm{gC} \mathrm{m}^{-2} \mathrm{yr}^{-1} \quad(P<0.01)$ over the 11 sites, which is comparable to the previous estimate $\left(57 \pm 34 \mathrm{gC} \mathrm{m}^{-2} \mathrm{yr}^{-1}\right)$ by Schulze et al. (2009) and lower than that (104 \pm $34 \mathrm{gC} \mathrm{m}^{-2} \mathrm{yr}^{-1}$ ) from the GREENGRASS network (Soussana et al., 2007). At both intensive and extensive grazed sites, a positive NBP indicative of a net annual carbon sink $\left(18-95 \mathrm{gC} \mathrm{m}^{-2} \mathrm{yr}^{-1}\right)$ is found in ORCHIDEE-GM. However, at sites dominated by cutting (including mixed site ITAmp and PT-Mi2), NBP is modeled to be less than grazed sites or even close zero.

\section{Discussion}

\subsection{Model performance for biometric variables}

The addition of an age-dependency of SLA allows intraannual SLA variation to be modeled in ORCHIDEE-GM, contrary to ORCHIDEE. A rapid increase in SLA during the growing season (Fig. 3) stems from the sprouting of 


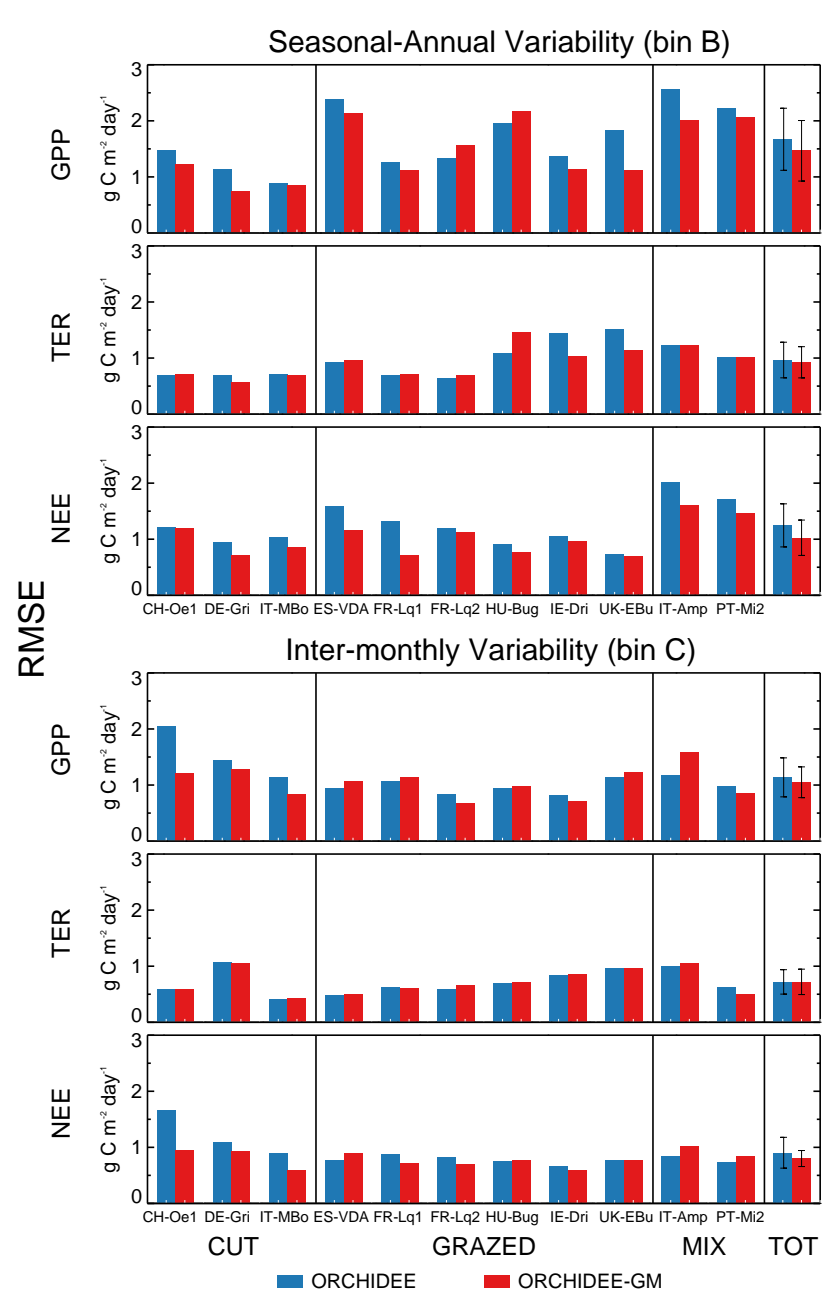

Fig. 7. Barplot of the root mean squared error (RMSE) between modeled and observed $\mathrm{CO}_{2}$ fluxes (GPP, TER and NEE) on seasonal-annual variability and intermonthly variability. Three management types (cut, grazed and mix-managed) are distinguished. TOT: the mean RMSE and its standard deviation based on all the sites.

new leaves (age class 1 with higher SLA) after cut or during the grazing, which helps the plants to capture photosynthetic sources and increase the LAI with a relatively small amount of biomass. ORCHIDEE-GM can better reproduce intra-annual variation in biometric variables (LAI and AGB) than ORCHIDEE. This improvement is more noticeable at cut sites than at grazed sites. It could be related to the difficulty for ORCHIDEE-GM in accounting for continuous disturbance and its induced complex animal-vegetation interactions (Vuichard et al., 2007a).

\subsection{Model performance for $\mathrm{CO}_{2}$ fluxes}

ORCHIDEE-GM reproduces intra-annual fluctuations of $\mathrm{CO}_{2}$ fluxes significantly affected by grassland management, either cut (Fig. 4) or grazed (Fig. 5). A better model

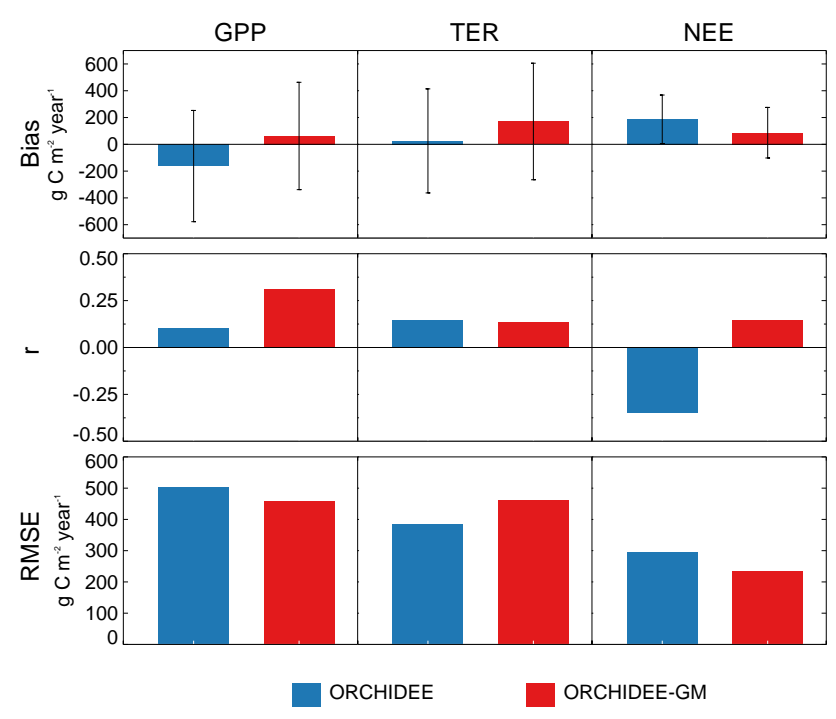

Fig. 8. Statistical performance of models on an interannual scale for $\mathrm{CO}_{2}$ fluxes (GPP, TER and NEE). Bias: mean model bias (modeled-observed, $\mathrm{gC} \mathrm{m}^{-2} \mathrm{yr}^{-1}$ ) over all site-years, error bar presents the standard deviation of biases; $r$ : correlation between observed and modeled interannual variability; RMSE: root mean squared error for interannual variability in annual totals of $\mathrm{CO}_{2}$ fluxes.

performance in ORCHIDEE-GM compared to ORCHIDEE on intermonthly and seasonal-annual scales is found for NEE and GPP. This further justifies the necessity to incorporate management processes in order to calculate the $\mathrm{CO}_{2}$ exchange on European grasslands, e.g., for being used as a better prior of atmospheric $\mathrm{CO}_{2}$ inversions. In addition, an increase in the ability to reproduce NEE at timescales of weeks to year can be attributed to a better simulation of GPP rather than TER that improves marginally. This might be due to the modeling issue of soil organic matter initial disequilibrium (Carvailhais et al., 2008). Improved GPP simulation by ORCHIDEE-GM comes from more accurate prediction of plant growth under management. However, the main component of TER is soil respiration. It is highly sensitive to soil organic matter amount, which is initialized by the same soil $\mathrm{C}$ module in ORCHIDEE rather than by field observations in this study.

Although ORCHIDEE-GM performs better on both timescales, systematically better at cut sites than at grazed sites, the improvement at grazed sites are more noticeable on the seasonal-annual than on the intermonthly timescales. This illustrates the fact that cut and grazing practices have different influences in the temporal variation of NEE, and that grazing has more impact on seasonal-annual than on intermonthly timescales. The large amplitude on intermonthly timescale (Fig. 6) indicates that the intense sporadic disturbance, e.g., cut, could also significantly influence $\mathrm{CO}_{2}$ fluxes. 


\subsection{Sources of model-data discrepancies}

\subsubsection{Initial soil organic matter}

All simulations in this study start from modeled steady state, then an arbitrate management history (e.g., $40 \mathrm{yr}$ ), rather than based on real soil $\mathrm{C}$ conditions, since the latter would require more detailed data on initial $\mathrm{C}$ pools of different turnover rates or on site history for the model to simulate the initial value of each carbon pool, compared to what is available. This initialization procedure may cause certain model-data discrepancies.

At CH-Oe1, for example, lower TER is simulated in ORCHIDEE-GM than the observations, which probably results from the simulated low soil organic $\mathrm{C}$ and low litter input. Before the year 2002, this site was exposed to a leyarable rotation management with a nitrogen fertilization of $110 \mathrm{kgN} \mathrm{ha}^{-1} \mathrm{yr}^{-1}$. ORCHIDEE-GM simulates a lower soil organic $\mathrm{C}\left(12.3 \mathrm{kgC} \mathrm{m}^{-2}\right.$ after $40 \mathrm{yr}$ of spin-up 2$)$ than observed (18.3 $\mathrm{kgC} \mathrm{m}^{-2}$ in 2004, Ammann et al., 2009). Moreover, a larger $\mathrm{C}$ export $\left(426 \mathrm{gC} \mathrm{m}^{-2} \mathrm{yr}^{-1}\right)$ than the observation $\left(\sim 350 \mathrm{gC} \mathrm{m}^{-2} \mathrm{yr}^{-1}\right)$ is also found in ORCHIDEE-GM, and then less biomass has thus been left as the litter input.

\subsubsection{Site specific parameters}

As in other DGVMs, ORCHIDEE simulates an average plant and consequently it only defines average plant functional traits for each PFT, such as mean SLA, the maximal rate of carboxylation $\left(\mathrm{Vc}_{\max }\right)$ and the light saturate rate of electron transport $\left(J_{\max }\right)$. However, these traits are highly sitespecific. Plants allocate $\mathrm{N}$ to maintain a balance between $\mathrm{Vc}_{\max }$ and $J_{\max }$ (usually with a close correlation of $J_{\max } \approx$ $2 \times \mathrm{Vc}_{\max }$, Wullschleger, 1993), which are both dependent on leaf $\mathrm{N}$ concentrations and potentially limit photosynthesis (Chen et al., 1993). Nutrient (most notably N) limitation also strongly impacts the whole-plant leaf area (Poorter et al., 2009). Then, the soil $\mathrm{N}$ availability could be a strong limitation of plant growth. ORCHIDEE cannot fully consider the coordination of leaf nitrogen distribution due to the lack of nitrogen cycle, thus preventing simulations of these sitespecific parameters.

This model deficiency in capturing site-specific parameters might introduce the errors in carbon simulations. It can be exemplified by calibrating $\mathrm{SLA}_{\max }$ and $\mathrm{Vc}_{\max }$ of ORCHIDEE-GM based on in situ measurements (mean SLA and $\mathrm{Vc}_{\max }$ ) available at two sites: (i) the intensively grazed and highly fertilized grassland FR-Lq1, and (ii) the extensively grazed grassland FR-Lq2. Our analysis shows that the model errors in GPP, as well as in TER and NEE, are reduced when site-specific parameter values are used. At FRLq1, the RMSE reductions are $8.5 \%, 8.9 \%$ and $2.5 \%$ for GPP, TER and NEE, respectively. At FR-Lq2, optimized parameters improve model performance on GPP, TER and NEE (with RMSE reducing $6.0 \%, 3.4 \%$ and $3.5 \%$, respectively).
Our results indicate that wrong-setting values of site-specific parameters (e.g., SLA $\mathrm{Sax}_{\max }$ and $\mathrm{Vc}_{\max }$ ) could be one of sources for model-data disagreement. Interestingly to note is that these two parameters are tightly correlated with leaf $\mathrm{N}$ concentrations that are linked to $\mathrm{N}$ fertilizer inputs on the fields (Ordoñez et al., 2009).This implies that $\mathrm{SLA}_{\max }$ and $\mathrm{Vc}_{\max }$ could be potentially prescribed to vary spatially as a function of easily available $\mathrm{N}$ fertilizer statistical data in future regional simulations.

\subsubsection{Observation uncertainties}

For $\mathrm{CO}_{2}$ fluxes, NEE is directly measured by eddycovariance technique, but with certain site-dependent random errors from the measurements instruments, the stochastic nature of turbulence and varying footprint (area that influences the measurement) (e.g., Hollinger et al., 2004; Richardson and Hollinger, 2005; Richardson et al., 2006; Lasslop et al., 2008). Moreover, the two components GPP and TER are partitioned from NEE by statistical modeling (e.g., Reichstein et al., 2005), which contains certain uncertainties (Papale et al., 2006). In addition, certain data gaps due to unfavorable meteorological conditions and systematic errors in the NEE measurements (e.g., low turbulence occurs in nighttime) can also introduce uncertainties to be $\pm 25 \mathrm{gC} \mathrm{m}^{-2} \mathrm{yr}^{-1}$ (Moffat et al., 2007). All of these can contribute to the observed model-data discrepancies.

\subsection{A complete view of NBP}

In managed grasslands, the assimilated $\mathrm{C}$ by photosynthesis is not only used for ecosystem metabolism but exported by harvest, animal respiration and animal products. After the introduction of management, ORCHIDEE-GM is able to simulate forage yield, herbage consumption, animal products (e.g., milk), animal respiration and animal $\mathrm{CH}_{4}$ emissions. These new variables combined with organic $\mathrm{C}$ fertilizer applied on the field could provide a more complete view of grasslands $\mathrm{C}$ fluxes for applications of the model on a grid. The added organic fertilizer is also considered given the fact that it could play an important role in some intensively managed sites on sustaining soil fertility (e.g., CH-Oe1, IE-Dri, and UK-EBu). The 11 site simulations of this study show that European grasslands generally are C sink (positive NBP). At grazed grasslands, both $\mathrm{C}$ export in the form of milk production and $\mathrm{CH}_{4}$ emissions by animals constitute only a minor part of net primary production (NPP), and this means that NBP mainly depends on NPP. On the contrary, the cut sites accumulate less $\mathrm{C}$ in soils because a large part of NPP has been exported as forage production. Given a lower $\mathrm{C}$ usage at grazed grasslands than that at cut grasslands, the NBP difference between them indicates a possible relationship between the $C$ usage and NBP found by Soussana et al. (2007). This same relationship is also found within cut grasslands and grasslands having both grazing and cutting (Table 4). The 
Table 4. Model output related to management from ORCHIDEE-GM. Yield, mean annual forage production $\left(\mathrm{dry}^{\mathrm{matter}} \mathrm{g} \mathrm{m}^{-2} \mathrm{yr}^{-1}\right)$; intake, mean annual grass mass digested by animals (dry matter, $\left.\mathrm{g} \mathrm{m}^{-2} \mathrm{yr}^{-1}\right)$; respiration, mean annual animal respiration $\left(\mathrm{C}, \mathrm{g} \mathrm{m}^{-2} \mathrm{yr}^{-1}\right.$ ); MilkC, mean annual $\mathrm{C}$ export in milk production $\left(\mathrm{C}, \mathrm{g} \mathrm{m}^{-2} \mathrm{yr}^{-1}\right) ; \mathrm{CH}_{4}$, mean annual enteric $\mathrm{CH}_{4}$ emission $\left(\mathrm{C}_{-} \mathrm{CH}_{4}, \mathrm{~g} \mathrm{~m}^{-2} \mathrm{yr}^{-1}\right) ; \mathrm{NBP}$, net biome production $\left(\mathrm{C}, \mathrm{g} \mathrm{m}^{-2} \mathrm{yr}^{-1}\right)$.

\begin{tabular}{llrrrrrr}
\hline Management & Site & Yield & Intake & Respiration & MilkC & $\mathrm{CH}_{4}$ & NBP \\
\hline Cutting & CH-Oe1 & 975 & - & - & - & - & 3 \\
& DE-Gri & 760 & - & - & - & - & 10.0 \\
\multirow{5}{*}{ Grazing } & IT-MBo & 288 & - & - & - & - & 21.0 \\
& ES-VDA & - & 58 & 11.0 & 4.0 & 0.8 & 60.1 \\
& FR-Lq1 & - & 374 & 71.3 & - & 3.9 & 41.6 \\
& FR-Lq2 & - & 250 & 47.6 & - & 0.7 & 57.7 \\
& HU-Bug & - & 176 & 33.5 & 15.0 & 2.3 & 37.9 \\
& IE-Dri & - & 272 & 51.8 & 20.7 & 3.5 & 68.1 \\
Cutting/grazing & UK-EBu & - & 231 & 44.1 & 14.3 & 3.9 & 94.5 \\
& IT-Amp & 301 & 65 & 12.5 & 3.4 & 1.8 & 3.5 \\
& PT-Mi2 & 110 & 43 & 8.2 & 2.6 & 0.8 & 11 \\
\hline
\end{tabular}

results from paired sites (FR-Lq1 and FR-Lq2, see Table 4) further confirm that increased $\mathrm{C}$ usage (higher herbage intake at extensively grazed grassland, FR-Lq1) may diminish $\mathrm{C}$ sequestration (lower NBP) in managed grasslands, given the fact that intensive grazing reduces LAI and further decline NPP (Parsons et al., 1983).

Fully accounting for NBP still takes into account dissolved organic/inorganic (DOC/DIC) C losses to water, which, however, is not implemented in ORCHIDEE-GM. If the average DOC/DIC loss estimated at European scale $(11 \pm$ $8 \mathrm{gC} \mathrm{m}^{-2} \mathrm{yr}^{-1}$; Siemens, 2003) reduced the NBP by $30 \%$, the residual NBP (positive, $P<0.05$ ) still indicates a $\mathrm{C}$ sequestration in European managed grasslands.

However, it should be noted that our estimation of NBP is biased by the fact that the model initialization of soil C pools is not realistic. Only long-term simulation with precise management history or initialization based on precise soil organic C (e.g., the European Soil Database; Panagos et al., 2012) can avoid this uncertainty when running the model on a grid for future applications. Nevertheless, a more complete picture of NBP provided by ORCHIDEE-GM enables us to separate the role of grassland management from those of other factors (e.g., $\mathrm{CO}_{2}$, climate and land use) in the attribution of the grassland $\mathrm{C}$ sequestration (Soussana et al., 2010).

\section{Conclusions}

This paper is an attempt to realistically represent the impact of management on the $\mathrm{C}$ fluxes of European grasslands in a DGVM. We developed a new model, ORCHIDEE-GM, integrating a management module from a grassland specific model (PaSim) and evaluated its results at 11 European sites. Generally, ORCHIDEE-GM is better able to reproduce intraannual variation of LAI, AGB, and $\mathrm{CO}_{2}$ fluxes (GPP, TER, and NEE) induced by cut or grazing practices. Model-data discrepancies can be attributed to lack of data to initialize soil $\mathrm{C}$ pools, to $\mathrm{CO}_{2}$ fluxes observation uncertainties and to some site-specific parameter values. The optimization of $\mathrm{N}$ related parameters (SLA, $\mathrm{Vc}_{\max }$, and $J_{\max }$ ) in ORCHIDEEGM reduces the model-data misfit at sites where it was performed. However, we should state that this study is not designed for fully bridging the gap in $\mathrm{C}$ fluxes simulations but more for understanding the contributing effect of improved management practices to $\mathrm{C}$ fluxes simulations in temperate grassland.

The simulated C fluxes of forage yield, herbage consumption, animal products (milk), animal respiration and methane emissions by ORCHIDEE-GM give a more complete picture of NBP in managed temperate grasslands. This model with its realistic management process could enable us to reexamine the $\mathrm{C}$ balance in the regions, such as Europe and China, which distribute a large area of managed temperate grasslands. Furthermore, it could also be adopted to understand the responses of forage yield or other GHGs to the ongoing climate change and investigate the feedback between surface albedo and air temperature induced by management practices (cut and grazing).

Acknowledgements. This work was made possible through the support of the CARBOEUROPE-IP and Nitroeurope project to eddy-covariance flux sites. Special thanks go to PIs for giving us access to their ancillary and flux data. We would like to thank Shiping Chen, who provided ancillary information for sites in China (CN-Du2, CN-Dwu, CN-Xi1 and CN-Xi2). We also acknowledge the $\mathrm{PhD}$ funding by Commissariat à l'énergie atomique (CEA) in France. Finally, we greatly thank Ray Anderson and the anonymous reviewers for their constructive comments on the manuscript.

Edited by: M.-H. Lo 
The publication of this article is financed by CNRS-INSU.

\section{References}

Abril, A. and Bucher, E. H.: The effects of overgrazing on soil microbial community and fertility in the chaco dry savannas of Argentina, Appl. Soil Ecol., 12, 159-167, 1999.

Ammann, C., Spirig, C., Leifeld, J., and Neftel, A.: Assessment of the nitrogen and carbon budget of two managed temperate grassland fields, Agr. Ecosyst. Environ., 133, 150-162, 2009.

Baldocchi, D., Falge, E., Gu, L., Olson, R., Hollinger, D., Running, S., Anthoni, P., Bernhofer, C., Davis, K., Evans, R., and Fuentes, J.: FLUXNET: A New Tool to Study the Temporal and Spatial Variability of Ecosystem-Scale Carbon Dioxide, Water Vapor, and Energy Flux Densities, B. Am. Meteorol. Soc., 82, 24152434, 2001.

Berg, B. and Matzner, E.: Effect of $\mathrm{N}$ deposition on decomposition of plant litter and soil organic matter in forest systems, Environ. Rev. 5, 1-25, 1997.

Béziat, P., Ceschia, E., and Dedieu, G.: Carbon balance of a three crop succession over two cropland sites in south west france, Agr. Forest. Meteorol., 149, 1628-1645, 2009.

Bondeau, A., Smith, P. C., Zaehle, S., Schaphoff, S., Lucht, W., Cramer, W., Gerten, D., Lotze-Campen, H., Mueller, C., Reichstein, M., and Smith, B.: Modelling the role of agriculture for the 20th century global terrestrial carbon balance, Global. Change. Biol., 13, 679-706, 2007.

Broomhead, D. S. and King, G. P.: Extracting qualitative dynamics from experimental-data, Physica D, 20, 217-236, 1986.

Byrne, K. A., Kiely, G., and Leahy, P.: Carbon sequestration determined using farm scale carbon balance and eddy covariance, Agr. Ecosyst. Environ., 121, 357-364, 2007.

Carvalhais, N., Reichstein, M., Seixas, J., Collatz, G. J., Pereira, J. S., Berbigier, P., Carrara, A., Granier, A., Montagnani, L., Papale, D., Rambal, S., Sanz, M. J., and Valentini, R.: Implications of the carbon cycle steady state assumption for biogeochemical modeling performance and inverse parameter retrieval, Global Biogeochem. Cy. 22, GB2007, doi:10.1029/2007GB003033, 2008.

Chen, D. X., Hunt, H. W., and Morgan, J. A.: Responses of a C3 and $\mathrm{C} 4$ perennial grass to $\mathrm{CO}_{2}$ enrichment and climate change: Comparison between model predictions and experimental data, Ecol. Model., 87, 11-27, 1996.

Chen, J. L., Reynolds, J. F., Harley, P. C., and Tenhunen, J. D.: Coordination theory of leaf nitrogen distribution in a canopy, Oecologia, 93, 63-69, 1993.

Ciais, P., Reichstein, M., Viovy, N., Granier, A., Ogee, J., Allard, V., Aubinet, M., Buchmann, N., Bernhofer, C., Carrara, A., Chevallier, F., De Noblet, N., Friend, A. D., Friedlingstein, P., Grunwald, T., Heinesch, B., Keronen, P., Knohl, A., Krinner, G., Loustau, D., Manca, G., Matteucci, G., Miglietta, F., Ourcival, J. M., Papale, D., Pilegaard, K., Rambal, S., Seufert, G., Soussana, J. F., Sanz, M. J., Schulze, E. D., Vesala, T., and Valentini, R.: Europewide reduction in primary productivity caused by the heat and drought in 2003, Nature 437, 529-533, 2005.
Conant, R. T., Paustian, K., and Elliott, E. T.: Grassland management and conversion into grassland: Effects on soil carbon, Ecol. Appl., 11, 343-355, 2001.

Dolman, A. J., Noilhan, J., Durand, P., Sarrat, C., Brut, A., Piguet, B., Butet, A., Jarosz, N., Brunet, Y., Loustau, D., Lamaud, E., Tolk, L., Ronda, R., Miglietta, F., Gioli, B., Magliulo, V., Esposito, M., Gerbig, C., Korner, S., Glademard, R., Ramonet, M., Ciais, P., Neininger, B., Hutjes, R. W. A., Elbers, J. A., Macatangay, R., Schrems, O., Perez-Landa, G., Sanz, M. J., Scholz, Y., Facon, G., Ceschia, E., and Beziat, P.: The CARBOEURPOE regional experiment strategy, B. Am. Meteorol. Soc., 87, 13671379, 2006.

Ducoudre, N. I., Laval, K., and Perrier, A.: Sechiba, a new set of parameterizations of the hydrologic exchanges at the land atmosphere interface within the lmd atmospheric general-circulation model, J. Climate, 6, 248-273, 1993.

Elsner, J. B. and Tsonis, A. A.: Singular Spectrum Analysis: A New Tool in Time Series Analysis, 164 pp., Plenum, New York, 1996.

Falge, E., Baldocchi, D., Olson, R. J., Anthoni, P., Aubinet, M., Bernhofer, C., Burba, G., Ceulemans, R., Clement, R., Dolman, H., Granier, A., Gross, P., Grünwald, T., Hollinger, D., Jensen, N.-O., Katul, G., Keronen, P., Kowalski, A., Ta Lai, C., Law, B. E., Meyers, T., Moncrieff, J., Moors, E., Munger, J. W., Pilegaard, K., Rannik, Ü., Rebmann, C., Suyker, A., Tenhunen, J., Tu, K., Verma, S., Vesala, T., Wilson, K., and Wofsy, S.: Gap filling strategies for defensible annual sums of net ecosystem exchange, Agr. Meteorol., 107, 43-69, 2001.

Fearnside, P. M. and Barbosa, R. I.: Soil carbon changes from conversion of forest to pasture in brazilian amazonia, Forest. Ecol. Manage., 108, 147-166, 1998.

Feddema, J., Oleson, K., Bonan, G., Mearns, L., Washington, W., Meehl, G., and Nychka, D.: A comparison of a GCM response to historical anthropogenic land cover change and model sensitivity to uncertainty in present-day land cover representations, Clim. Dynam., 25, 581-609, 2005.

Foley, J. A., DeFries, R., Asner, G. P., Barford, C., Bonan, G., Carpenter, S. R., Chapin, F. S., Coe, M. T., Daily, G. C., Gibbs, H. K., Helkowski, J. H., Holloway, T., Howard, E. A., Kucharik, C. J., Monfreda, C., Patz, J. A., Prentice, I. C., Ramankutty, N., and Snyder, P. K.: Global consequences of land use, Science, 309, 570-574, 2005.

Foy, J. K., Teague, W. R., and Hanson, J. D.: Evaluation of the upgraded SPUR model (SPUR2.4), Ecol. Model., 118, 149-165, 1999.

Ghil, M., Allen, M. R., Dettinger, M. D., Ide, K., Kondrashov, D., Mann, M. E., Robertson, A. W., Saunders, A., Tian, Y., Varadi, F., and Yiou, P.: Advanced spectral methods for climatic time series, Rev. Geophys., 40, 1003, doi:10.1029/2000RG000092, 2002.

Gilmanov, T. G., Soussana, J. E., Aires, L., Allard, V., Ammann, C., Balzarolo, M., Barcza, Z., Bernhofer, C., Campbell, C. L., Cernusca, A., Cescatti, A., Clifton-Brown, J., Dirks, B. O. M., Dore, S., Eugster, W., Fuhrer, J., Gimeno, C., Gruenwald, T., Haszpra, L., Hensen, A., Ibrom, A., Jacobs, A. F. G., Jones, M. B., Lanigan, G., Laurila, T., Lohila, A., Manca, G., Marcolla, B., Nagy, Z., Pilegaard, K., Pinter, K., Pio, C., Raschi, A., Rogiers, N., Sanz, M. J., Stefani, P., Sutton, M., Tuba, Z., Valentini, R., Williams, M. L., and Wohlfahrt, G.: Partitioning European grassland net ecosystem $\mathrm{CO}_{2}$ exchange into gross primary pro- 
ductivity and ecosystem respiration using light response function analysis, Agr. Ecosyst. Environ., 121, 93-120, 2007.

Golyandina, N., Nekrutkin, V., and Zhigljavsky, A.: Analysis of Time Series Structure: SSA and Related Techniques, Monogr. Stat. Appl. Probab., Vol. 90, 305 pp., CRC Press, Boca Raton, Fla, 2001.

Graux, A. I., Gaurut, M., Agabriel, J., Baumont, R., Delagarde, R., Delaby, L., and Soussana, J. F.: Development of the pasture simulation model for assessing livestock production under climate change, Agr. Ecosyst. Environ., 144, 69-91, 2011.

Graux, A. I., Lardy, R., Bellocchi, G., and Soussana, J. F.: Global warming potential of French grassland-based dairy livestock systems under climate change, Reg. Environ. Change, 12, 751-763, doi:10.1007/s10113-012-0289-2, 2012.

Graux, A. I., Lardy, R., Bellocchi, G., and Soussana, J. F.: Ensemble modelling of climate change risks and opportunities for managed grasslands in France, Agr. Forest. Meteorol., 170, 114-131, 2013.

Gulden, L. E., Rosero, E., Yang, Z. L., Wagener, T., and Niu, G. Y.: Model performance, model robustness, and model fitness scores: A new method for identifying good land surface models, Geophys. Res. Lett., 35, L11404, doi:10.1029/2008GL033721, 2008.

Haase, P., Pugnaire, F. I., Clark, S. C., and Incoll, L. D.: Environmental control of canopy dynamics and photosynthetic rate in the evergreen tussock grass stipa tenacissima, Plant Ecol., 145, 327-339, 1999

Hollinger, D. Y., Aber, J., Dail, B., Davidson, E. A., Goltz, S. M., Hughes, H., Leclerc, M. Y., Lee, J. T., Richardson, A. D., Rodrigues, C., Scott, N., Achuatavarier, D., and Walsh, J.: Spatial and temporal variability in forest-atmosphere $\mathrm{CO}_{2}$ exchange, Global Change Biol., 10, 1689-1706, 2004.

Hunt, H. W., Trlica, M. J., Redente, E. F., Moore, J. C., Detling, J. K., Kittel, T. G. F., Walter, D. E., Fowler, M. C., Klein, D. A., and Elliott, E. T.: Simulation-model for the effects of climate change on temperate grassland ecosystems, Ecol. Model., 53, 205-246, 1991.

Jones, M. B. and Donnelly, A.: Carbon sequestration in temperate grassland ecosystems and the influence of management, climate and elevated $\mathrm{CO}_{2}$, New Phytol., 164, 423-439, 2004.

Kattge, J., Diaz, S., Lavorel, S., Prentice, C., Leadley, P., Boenisch, G., Garnier, E., Westoby, M., Reich, P. B., Wright, I. J., Cornelissen, J. H. C., Violle, C., Harrison, S. P., van Bodegom, P. M., Reichstein, M., Enquist, B. J., Soudzilovskaia, N. A., Ackerly, D. D., Anand, M., Atkin, O., Bahn, M., Baker, T. R., Baldocchi, D., Bekker, R., Blanco, C. C., Blonder, B., Bond, W. J., Bradstock, R., Bunker, D. E., Casanoves, F., Cavender-Bares, J., Chambers, J. Q., Chapin III, F. S., Chave, J., Coomes, D., Cornwell, W. K., Craine, J. M., Dobrin, B. H., Duarte, L., Durka, W., Elser, J., Esser, G., Estiarte, M., Fagan, W. F., Fang, J., FernandezMendez, F., Fidelis, A., Finegan, B., Flores, O., Ford, H., Frank, D., Freschet, G. T., Fyllas, N. M., Gallagher, R. V., Green, W. A., Gutierrez, A. G., Hickler, T., Higgins, S. I., Hodgson, J. G., Jalili, A., Jansen, S., Joly, C. A., Kerkhoff, A. J., Kirkup, D., Kitajima, K., Kleyer, M., Klotz, S., Knops, J. M. H., Kramer, K., Kuehn, I., Kurokawa, H., Laughlin, D., Lee, T. D., Leishman, M., Lens, F., Lenz, T., Lewis, S. L., Lloyd, J., Llusia, J., Louault, F., Ma, S., Mahecha, M. D., Manning, P., Massad, T., Medlyn, B. E., Messier, J., Moles, A. T., Mueller, S. C., Nadrowski, K., Naeem, S., Niinemets, U., Noellert, S., Nueske, A., Ogaya, R.,
Oleksyn, J., Onipchenko, V. G., Onoda, Y., Ordonez, J., Overbeck, G., Ozinga, W. A., Patino, S., Paula, S., Pausas, J. G., Penuelas, J., Phillips, O. L., Pillar, V., Poorter, H., Poorter, L., Poschlod, P., Prinzing, A., Proulx, R., Rammig, A., Reinsch, S., Reu, B., Sack, L., Salgado-Negret, B., Sardans, J., Shiodera, S., Shipley, B., Siefert, A., Sosinski, E., Soussana, J.-F., Swaine, E., Swenson, N., Thompson, K., Thornton, P., Waldram, M., Weiher, E., White, M., White, S., Wright, S. J., Yguel, B., Zaehle, S., Zanne, A. E., and Wirth, C.: Try - a global database of plant traits, Global. Change. Biol., 17, 2905-2935, 2011.

Krinner, G., Viovy, N., de Noblet-Ducoudre, N., Ogee, J., Polcher, J., Friedlingstein, P., Ciais, P., Sitch, S., and Prentice, I. C.: A dynamic global vegetation model for studies of the coupled atmosphere-biosphere system, Global. Biogeochem. Сy., 19, GB1015, doi:10.1029/2003GB002199, 2005.

Lasslop, G., Reichstein, M., Kattge, J., and Papale, D.: Influences of observation errors in eddy flux data on inverse model parameter estimation, Biogeosciences, 5, 1311-1324, doi:10.5194/bg5-1311-2008, 2008

LeCain, D. R., Morgan, J. A., Schuman, G. E., Reeder, J. D., and Hart, R. H.: Carbon exchange and species composition of grazed pastures and exclosures in the shortgrass steppe of colorado, Agr. Ecosyst. Environ., 93, 421-435, 2002.

Legates, D. R. and McCabe, G. J.: Evaluating the use of "goodnessof-fit" measures in hydrologic and hydroclimatic model validation, Water Resour. Res., 35, 233-241, 1999.

Mahecha, M. D., Reichstein, M., Lange, H., Carvalhais, N., Bernhofer, C., Grünwald, T., Papale, D., and Seufert, G.: Characterizing ecosystem-atmosphere interactions from short to interannual time scales, Biogeosciences, 4, 743-758, doi:10.5194/bg-4-7432007, 2007.

Mahecha, M. D., Reichstein, M., Jung, M., Seneviratne, S. I., Zaehle, S., Beer, C., Braakhekke, M. C., Carvalhais, N., Lange, H., Le Maire, G., and Moors, E.: Comparing observations and process-based simulations of biosphere-atmosphere exchanges on multiple timescales, J. Geophys. Res.-Biogeosciences, 115, G02003, doi:10.1029/2009JG001016, 2010.

Moffat, A. M., Papale, D., Reichstein, M., Hollinger, D. Y., Richardson, A. D., Barr, A. G., Beckstein, C., Braswell, B. H., Churkina, G., Desai, A. R., Falge, E., Gove, J. H., Heimann, M., Hui, D., Jarvis, A. J., Kattge, J., Noormets, A., and Stauch, V. J.: Comprehensive comparison of gap-filling techniques for eddy covariance net carbon fluxes, Agr. Forest. Meteorol., 147, 209-232, 2007.

Ordoñez, J. C., van Bodegom, P. M., Witte, J.-P. M., Wright, I. J., Reich, P. B., and Aerts, R.: A global study of relationships between leaf traits, climate and soil measures of nutrient fertility, Global Ecol. Biogeogr., 18, 138-149, 2009.

Panagos, P., Van Liedekerke, M., Jones, A., and Montanarella, L.: European Soil Data Centre: Response to European policy support and public data requirements, Land Use Policy, 29, 329-338, 2012.

Papale, D., Reichstein, M., Aubinet, M., Canfora, E., Bernhofer, C., Kutsch, W., Longdoz, B., Rambal, S., Valentini, R., Vesala, T. and Yakir, D.: Towards a standardized processing of Net Ecosystem Exchange measured with eddy covariance technique: algorithms and uncertainty estimation, Biogeosciences, 3, 571-583, doi:10.5194/bg-3-571-2006, 2006.

Parsons, A. J., Leafe, E. L., Collett, B., Penning, P. D., and Lewis, J.: The physiology of grass production under grazing. II. Photo- 
synthesis, crop growth and animal intake of continuously grazed swards, J. Appl. Ecol., 20, 127-139, 1983.

Parton, W. J., Stewart, J. W. B., and Cole, C. V.: Dynamics of C, N, $\mathrm{P}$ and $\mathrm{S}$ in grassland soils - a model, Biogeochemistry, 5, 109131, 1988.

Piao, S., Friedlingstein, P., Ciais, P., de Noblet-Ducoudre, N., Labat, D., and Zaehle, S.: Changes in climate and land use have a larger direct impact than rising $\mathrm{CO}_{2}$ on global river runoff trends, Proceedings of the National Academy of Sciences of the United States of America, 104, 15242-15247, 2007.

Pinares-Patiňo, C. S., D’Hour, P., Jouany, J. P., and Martin, C.: Effects of stocking rate on methane and carbon dioxide emissions from grazing cattle, Agr. Ecosyst. Environ., 121, 30-46, 2007.

Poorter, H., Niinemets, U., Poorter, L., Wright, I. J., and Villar, R.: Causes and consequences of variation in leaf mass per area (LMA): A meta-analysis, New Phytol., 182, 565-588, 2009.

Reeder, J. D. and Schuman, G. E.: Influence of livestock grazing on c sequestration in semi-arid mixed-grass and short-grass rangelands, Environ. Pollut., 116, 457-463, 2002.

Reichstein, M., Falge, E., Baldocchi, D., Papale, D., Aubinet, M., Berbigier, P., Bernhofer, C., Buchmann, N., Gilmanov, T., Granier, A., Grunwald, T., Havrankova, K., Ilvesniemi, H., Janous, D., Knohl, A., Laurila, T., Lohila, A., Loustau, D., Matteucci, G., Meyers, T., Miglietta, F., Ourcival, J. M., Pumpanen, J., Rambal, S., Rotenberg, E., Sanz, M., Tenhunen, J., Seufert, G., Vaccari, F., Vesala, T., Yakir, D., and Valentini, R.: On the separation of net ecosystem exchange into assimilation and ecosystem respiration: Review and improved algorithm, Global. Change. Biol., 11, 1424-1439, 2005.

Richardson, A. D. and Hollinger, D. Y.: Statistical modeling of ecosystem respiration using eddy covariance data: maximum likelihood parameter estimation, and Monte Carlo simulation of model and parameter uncertainty, applied to three simple models, Agr. Forest Meteorol., 131, 191-208, 2005.

Richardson, A. D., Hollinger, D. Y., Burba, G. G., Davis, K. J., Flanagan, L. B., Katul, G. G., Munger, J. W., Ricciuto, D. M., Stoy, P. C., Suyker, A. E., Verma, S. B., and Wofsy, S. C.: A multi-site analysis of random error in tower-based measurements of carbon and energy fluxes, Agr. Forest Meteorol., 136, 1-18, 2006.

Riedo, M., Grub, A., Rosset, M., and Fuhrer, J.: A pasture simulation model for dry matter production, and fluxes of carbon, nitrogen, water and energy, Ecol. Model., 105, 141-183, 1998.

Riedo, M., Gyalistras, D., and Fuhrer, J.: Net primary production and carbon stocks in differently managed grasslands: Simulation of site-specific sensitivity to an increase in atmospheric $\mathrm{CO}_{2}$ and to climate change, Ecol. Model., 134, 207-227, 2000.

Riedo, M., Milford, C., Schmid, M., and Sutton, M. A.: Coupling soil-plant-atmosphere exchange of ammonia with ecosystem functioning in grasslands, Ecol. Model., 158, 83-110, 2002.

Rodriguez, D., Van Oijen, M., and Schapendonk, A.: Lingra-cc: A sink-source model to simulate the impact of climate change and management on grassland productivity, New Phytol., 144, 359368,1999

Schapendonk, A., Stol, W., van Kraalingen, D. W. G., and Bouman, B. A. M.: Lingra, a sink/source model to simulate grassland productivity in Europe, Eur. J. Agron., 9, 87-100, 1998.

Schmid, M., Fuhrer, J., and Neftel, A.: Nitrous oxide concentrations in the soil of a mown grassland: comparison of model results with soil profile measurements, Water Air Soil Poll., 1, 437-446, $2001 \mathrm{a}$.

Schmid, M., Neftel, A., Riedo, M., and Fuhrer, J.: Process-based modelling of nitrous oxide emissions from different nitrogen sources in mown grassland, Nutr. Cycl. Agroecosys, 60, 177187, 2001b.

Schnyder, H. and de Visser, R.: Fluxes of reserve-derived and currently assimilated carbon and nitrogen in perennial ryegrass recovering from defoliation. The regrowing tiller and its component functionally distinct zones, Plant Physiol., 119, 1423-1435, 1999.

Schulze, E. D., Luyssaert, S., Ciais, P., Freibauer, A., Janssens, I. A., Soussana, J. F., Smith, P., Grace, J., Levin, I., Thiruchittampalam, B., Heimann, M., Dolman, A. J., Valentini, R., Bousquet, P., Peylin, P., Peters, W., Roedenbeck, C., Etiope, G., Vuichard, N., Wattenbach, M., Nabuurs, G. J., Poussi, Z., Nieschulze, J., Gash, J. H., and CarboEurope, T.: Importance of methane and nitrous oxide for europe's terrestrial greenhouse-gas balance, Nat. Geosci., 2, 842-850, 2009.

Schulze, E. D., Ciais, P., Luyssaert, S., Schrumpf, M., Janssens, I. A., Thiruchittampalam, B., Theloke, J., Saurat, M., Bringezu, S., Lelieveld, J., Lohila, A., Rebmann, C., Jung, M., Bastviken, D., Abril, G., Grassi, G., Leip, A., Freibauer, A., Kutsch, W., Don, A., Nieschulze, J., Boerner, A., Gash, J. H., and Dolman, A. J.: The European carbon balance. Part 4: Integration of carbon and other trace-gas fluxes, Global. Change. Biol., 16, 1451-1469, 2010.

Schuman, G. E., Reeder, J. D., Manley, J. T., Hart, R. H., and Manley, W. A.: Impact of grazing management on the carbon and nitrogen balance of a mixed-grass rangeland, Ecol. Appl., 9, 65$71,1999$.

Scurlock, J. M. O. and Hall, D. O.: The global carbon sink: A grassland perspective, Global. Change. Biol., 4, 229-233, 1998.

Siemens, J.: The European carbon budget: a gap, Science, 302, p. 1681, doi:10.1126/science.302.5651.1681a, 2003

Soussana, J. F., Loiseau, P., Vuichard, N., Ceschia, E., Balesdent, J., Chevallier, T., and Arrouays, D.: Carbon cycling and sequestration opportunities in temperate grasslands, Soil Use. Manage., 20, 2190-230, 2004.

Soussana, J. F., Allard, V., Pilegaard, K., Ambus, P., Amman, C., Campbell, C., Ceschia, E., Clifton-Brown, J., Czobel, S., Domingues, R., Flechard, C., Fuhrer, J., Hensen, A., Horvath, L., Jones, M., Kasper, G., Martin, C., Nagy, Z., Neftel, A., Raschi, A., Baronti, S., Rees, R. M., Skiba, U., Stefani, P., Manca, G., Sutton, M., Tubaf, Z., and Valentini, R.: Full accounting of the greenhouse gas $\left(\mathrm{CO}_{2}, \mathrm{~N}_{2} \mathrm{O}, \mathrm{CH}_{4}\right)$ budget of nine European grassland sites, Agr. Ecosyst. Environ., 121, 121-134, 2007.

Soussana, J. F., Tallec, T., and Blanfort, V.: Mitigating the greenhouse gas balance of ruminant production systems through carbon sequestration in grasslands, Animal, 4, 334-350, 2010.

Suttie, J. M., Reynolds, S. G., and Batello, C.: Grasslands of the World, FAO Plant Production and Protection Series, FAO, 2005.

Thornley, J. H. M.: Grassland Dynamics: An Ecosystem Simulation Model, 241 pp., CABI Publ., Cambridge, Mass, 1998.

Viovy, N. and de Noblet, N.: Coupling water and Carbon cycle in the biosphere, Sci. Géol. Bull., 50, 109-121, 1997.

Vuichard, N.: Modélisation des flux de gaz à effet de serre des prairies européennes, Ph.D. thesis, Univ. Pierre et Marie Curie, Paris, 2005. 
Vuichard, N., Ciais, P., Viovy, N., Calanca, P., and Soussana, J.-F.: Estimating the greenhouse gas fluxes of European grasslands with a process-based model: 2. Simulations at the continental level, Global. Biogeochem. Cy., 21, GB1005, doi:10.1029/2005GB002612, 2007a.

Vuichard, N., Soussana, J.-F., Ciais, P., Viovy, N., Ammann, C., Calanca, P., Clifton-Brown, J., Fuhrer, J., Jones, M., and Martin, C.: Estimating the greenhouse gas fluxes of European grasslands with a process-based model: 1 . Model evaluation from in situ measurements, Global. Biogeochem. Cy., 21, GB1004, doi:10.1029/2005GB002611, 2007b.
Willmott, C. J., Ackleson, S. G., Davis, R. E., Feddema, J. J., Klink, K. M., Legates, D. R., Odonnell, J., and Rowe, C. M.: Statistics for the evaluation and comparison of models, J. Geophys. Res.Oceans, 90, 8995-9005, 1985.

Wullschleger, S. D.: Biochemical limitations to carbon assimilation in $\mathrm{C} 3$ plants - a retrospective analysis of the $\mathrm{A} / \mathrm{Ci}$ curves from 109 species, J. Exp. Bot., 44, 907-920, 1993. 